\title{
Gene-Stress-Epigenetic Regulation of FKBP5: Clinical and Translational Implications
}

\author{
Anthony S Zannas ${ }^{1,2}$, Tobias Wiechmann ${ }^{1}$, Nils C Gassen ${ }^{1}$ and Elisabeth B Binder, 1,3 \\ ${ }^{1}$ Department of Translational Research in Psychiatry, Max Planck Institute of Psychiatry, Munich, Germany; ${ }^{2}$ Department of \\ Psychiatry and Behavioral Sciences, Duke University Medical Center, Durham, NC, USA; ${ }^{3}$ Department of Psychiatry and \\ Behavioral Sciences, Emory University Medical School, Atlanta, GA, USA
}

Stress responses and related outcomes vary markedly across individuals. Elucidating the molecular underpinnings of this variability is of great relevance for developing individualized prevention strategies and treatments for stress-related disorders. An important modulator of stress responses is the FK506-binding protein 51 (FKBP5/FKBP51). FKBP5 acts as a cochaperone that modulates not only glucocorticoid receptor activity in response to stressors but also a multitude of other cellular processes in both the brain and periphery. Notably, the FKBP5 gene is regulated via complex interactions among environmental stressors, FKBP5 genetic variants, and epigenetic modifications of glucocorticoid-responsive genomic sites. These interactions can result in FKBP5 disinhibition that has been shown to contribute to a number of aberrant phenotypes in both rodents and humans. Consequently, FKBP5 blockade may hold promise as treatment intervention for stress-related disorders, and recently developed selective FKBP5 blockers show encouraging results in vitro and in rodent models. Although risk for stress-related disorders is conferred by multiple environmental and genetic factors, the findings related to FKBP5 illustrate how a deeper understanding of the molecular and systemic mechanisms underlying specific gene-environment interactions may provide insights into the pathogenesis of stress-related disorders.

Neuropsychopharmacology Reviews (2016) 41, 26I-274; doi: I 0. 1038/npp.20I5.235; published online 2 September 2015

\section{INTRODUCTION}

Psychological stress is a well-established risk factor for a multitude of disease phenotypes. Stressor exposure, including psychological stress, has been linked with a host of psychiatric disorders, including posttraumatic stress disorder (PTSD), major depression (MDD) (Kendler et al, 1999), cognitive impairment (Tsolaki et al, 2009), psychotic disorders (van Winkel et al, 2008), and addictions (Sinha, 2007). Furthermore, psychological stress has been shown to impact risk for medical conditions, such as cardiovascular disease, cancer, and immune disorders (Cohen et al, 2007; Kaltsas et al, 2012). Given that stress-related medical and psychiatric conditions are among the leading causes of morbidity and mortality, improved understanding of how stress contributes to their pathogenesis could have tremendous implications for reducing disease burden on individuals and societies.

${ }^{*}$ Correspondence: Dr E Binder, Department of Translational Research in Psychiatry, Max Planck Institute of Psychiatry, Kraepelinstrasse 2-10, Munich 80804, Germany, Tel: +49 8930622301 , Fax: +49 8930622610 , E-mail: binder@psych.mpg.de

Received 1 May 2015; revised 6 July 2015; accepted 7 July 2015; accepted article preview online 13 August 2015
Outcomes following stressor exposure vary markedly across individuals. For example, despite the ubiquity of traumatic events in human societies, only a proportion of individuals develops PTSD following trauma exposure (Galea et al, 2005), and several individuals may even show positive psychological changes, known as posttraumatic growth (PTG) (Jin et al, 2014). In line with these findings in humans, distinct rodent strains show variable rates of negative behavioral outcomes following similar stressors (Russo et al, 2012; Uchida et al, 2011). Substantial heterogeneity exists even for negative outcomes that follow stressor exposure. For example, exposure of different individuals to similar traumatic experiences may lead to the development of PTSD, MDD, or a combination of the two phenotypes (Belleville et al, 2012; Nillni et al, 2013). These pleiotropic effects of stressor exposure likely result from complex interactions among stressful experiences over the lifetime, other environmental factors, and multiple genetic and epigenetic factors that modulate stress responses and can shape stress-related phenotypes (Zannas and West, 2014b).

An important modulator of stress responses and the focus of this review is FK506-binding protein 51 (FKBP5/FKBP51), 
which, among other functions, acts as a co-chaperone that modulates glucocorticoid receptor (GR) activity. In the first section, we will introduce the molecular mechanisms through which FKBP5 is not only induced by stressors and interacts with the GR but also with other molecular partners to impact a number of cellular processes. Subsequently, we will focus on gene-environment-epigenetic interactions that regulate FKBP5 levels, and we will highlight the pleiotropic consequences of FKBP5 disinhibition. Finally, we will discuss the clinical and translational implications of these molecular mechanisms and future directions for this line of research.

\section{ROLE OF FKBP5 IN GR SIGNALING AND STRESS RESPONSES}

Several studies have shown that FKBP5 exerts an inhibitory role on GR signaling with intracellular as well as systemic effects. FKBP51/FKBP5 is a $51-\mathrm{kDa}$ immunophilin that belongs to the family of FK506-binding proteins, originally named after their ability to bind the immunosuppressant FK506 (Wiederrecht et al, 1992). Functional characterization of FKBP5 revealed that it has peptidyl-prolyl cis-trans isomerase activity and contains a tetratricopeptide repeat protein domain (Schiene-Fischer and Yu, 2001; Schmidt et al, 2012), which enables the protein to act as a co-chaperone that changes folding and activity of other proteins. Among the multiple molecular interactions of FKBP5 and particularly important for stress regulation is its binding to heat-shock protein 90 (Hsp90), P23 protein, and other co-chaperones of the steroid receptor complex (Schiene-Fischer and $\mathrm{Yu}, 2001$ ). By interacting with this complex, FKBP5 can modulate sensitivity of the GR. In particular, in vitro experiments have shown that FKBP5 reduces interaction of the GR complex with the transport protein dynein, delays nuclear translocation of the GR, and decreases GR-dependent transcriptional activity (Wochnik et al, 2005). Upon glucocorticoid binding, however, FKBP5 is exchanged for FK506-binding protein 52 (FKBP52/FKBP4), a co-chaperone that recruits dynein to the GR complex and promotes nuclear translocation and transcriptional regulation (Davies et al, 2002; Wochnik et al, 2005). The role of FKBP5 in GR signaling is summarized in Figure 1.

To understand how the above-described effects of intracellular regulation of GR-sensitivity affect stress responsivity at the organismal level, it is important to briefly review the function of the primary effector of the stress response, the hypothalamic-pituitary-adrenal (HPA) axis. The HPA axis is initiated via input of cortical and limbic brain regions at the paraventricular nucleus (PVN) of the hypothalamus, which releases corticotropin-releasing hormone (CRH) and angiotensin vasopressin that act on the anterior pituitary to stimulate the secretion of ACTH into the peripheral blood stream. This peptide hormone then promotes the adrenal secretion of glucocorticoids (Chrousos and Gold, 1992). Circulating glucocorticoids exert actions in essentially every body organ via activation of two receptors, the high affinity mineralocorticoid receptor (MR) and the lower affinity GR. Both are intracellular receptors, which after nuclear translocation can activate or repress a large number of glucocorticoid-responsive genes (Nicolaides et al, 2014). In this review, we will focus on the GR, as MR-FKBP5 interactions are less well studied. The GR affects gene transcription not only by binding of its homodimer to glucocorticoid response element (GRE) sequences in regulatory regions of target genes (Bamberger et al, 1996) but also via GRE-independent interactions of the GR monomer with other transcription factors (Scheinman et al, 1995) (Figure 1). The pattern of GR-mediated transcriptional regulation is tissue specific and depends on the GR isoform expressed and the accessibility of genomic binding sites (Lu and Cidlowski, 2005; Nicolaides et al, 2014). In addition to regulating adaptive stress responses, including metabolism, immune activation, and cell proliferation and differentiation, GR activation mediates multiple negative feedback loops that restrain HPA axis activity. In the brain, GR activation leads to rapid inhibition of genes that encode mediators of the HPA axis, such as CRH and ACTH (Russell et al, 2010; Watts, 2005). Negative feedback regulation is also promoted by GR occupancy in the hippocampus (Sapolsky et al, 1990), a brain region that has been shown to suppress HPA basal activity and reactivity to stress (Jacobson and Sapolsky, 1991). Lastly, GR activation in multiple tissues results in rapid induction of FKBP5 transcription and translation (Jaaskelainen et al, 2011). Given the inhibitory effect of FKBP5 on GR activity, the intracellular GR-mediated FKBP5 induction creates an ultra-short, negative feedback loop that regulates GR activity (Denny et al, 2000; Zannas and Binder, 2014a; Figure 1).

By modulating GR signaling, FKBP5 has the potential to modulate the actions of glucocorticoids, hormones with pleiotropic effects that can affect essentially every body tissue (Chrousos and Gold, 1992; Nicolaides et al, 2014). In fact, the function of FKBP5 was initially discovered in New World monkeys, which have very high circulating glucocorticoid levels but usually do not present with any symptoms associated with this dysregulation. This has been attributed to inherently high FKBP5 levels that confer GR resistance (Scammell et al, 2001). As we discuss below, FKBP5 dysregulation, and in particular FKBP5 disinhibition, has been linked with a number of stress-related disorders.

\section{ROLE OF FKBP5 IN OTHER MOLECULAR PROCESSES}

Although in psychiatry and neuroscience FKBP5 is most commonly discussed as a modulator of glucocorticoid signaling, it is important to highlight that it also interacts with a host of other molecular partners, affecting several cellular processes. Detailed description of these processes is beyond the scope of this review, but the most important interactions of FKBP5 are summarized here and in more detail in Figure 2. As co-chaperone of the Hsp90 complex, 


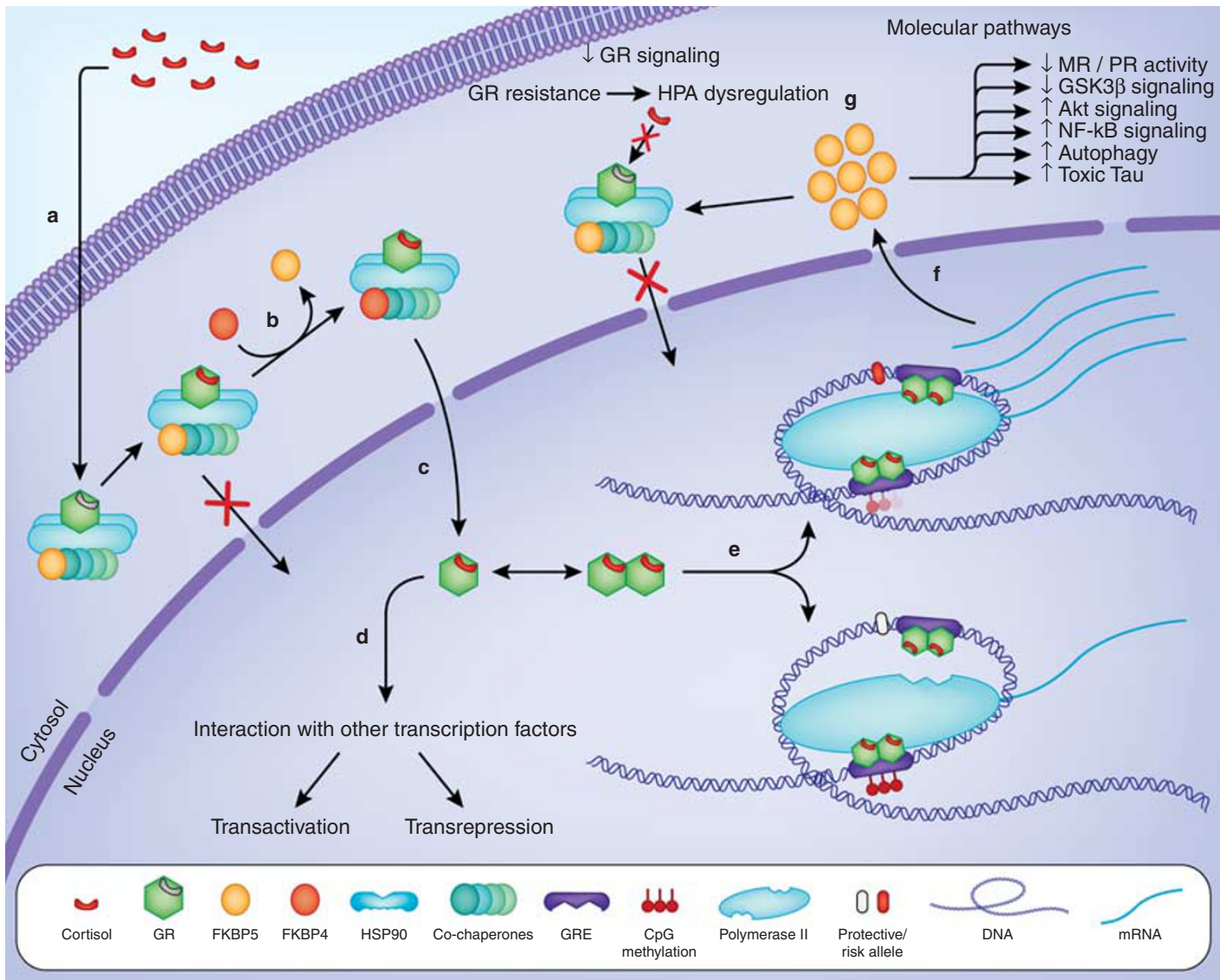

Figure 1. Schematic representation of the molecular events involved in glucocorticoid-mediated FKBP5 induction, the resulting intracellular negative feedback loop, and effects on other biological processes. Glucocorticoids enter the cytoplasm (a) and activate the glucocorticoid receptor (GR) complex. FKBP5 binding to the complex reduces affinity of glucocorticoids to the GR and delays translocation of the GR to the nucleus. However, exchange of FKBP5 for FKBP4 (b) results in GR translocation to the nucleus (c). The GR can either interact as a monomer with other transcription factors (d) or form a homodimer that binds to DNA at glucocorticoid response elements. Overall, GR functions result in transactivation or transrepression of a large number of genes. The FKBP5 gene is highly responsive to GR, but responsiveness depends on FKBP5 polymorphisms and methylation status (e). The synthesized FKBP5 mRNA translocates to the cytoplasm (f) where it is translated into FKBP5 protein. FKBP5 then inhibits GR activity not only forming an ultra-short, intracellular negative feedback loop of GR signaling but also modulating several other biological pathways (g).

FKBP5 interacts with steroid receptors other than the GR, including the $\mathrm{MR}$, progesterone (PR), estrogen (ER), and androgen (AR) receptors. Similar to its effects on GR, FKBP5 inhibits MR and PR activity (Barent et al, 1998; Gallo et al, 2007; Hubler et al, 2003), whereas it promotes ER and AR activity (Shrestha et al, 2015; Stechschulte and Sanchez, 2011), a function that may have important implications in the pathogenesis of prostate cancer (Stechschulte and Sanchez, 2011). Furthermore, FKBP5 has been shown to interact with molecular pathways involved in immune regulation and relevant for oncogenesis. In particular, FKBP5 interacts with and inhibits calcineurin (Baughman et al, 1995; Li et al, 2002; Weiwad et al, 2006) and interacts with the inhibitor of nuclear factor kappa-B (NF- $\kappa \mathrm{B})$ kinase subunit alpha (IKK- $\alpha$ ), promoting NF- $\kappa \mathrm{B}$ signaling (Bouwmeester et al, 2004; Romano et al, 2004). This latter effect has been implicated in the pathogenesis of melanoma, where FKBP5 has been suggested as a marker of malignant potential and FKBP5 blockade as possible treatment for this malignancy (Romano et al, 2010). FKBP5 has also been shown to negatively regulate protein kinase B (Akt) signaling, an interaction with important implications for cancer response to chemotherapy and cerebral ischemia/ reperfusion injury (Pei et al, 2009; Wei et al, 2014). This interaction could also exert effects on the mammalian target of rapamycin pathway, a pathway that is activated by Akt and has been implicated in the antidepressant activity of ketamine ( $\mathrm{Li}$ et al, 2010; Markman et al, 2010). More recently, FKBP5 was shown to have effects on autophagy and on the glycogen synthase kinase 3 beta and these may contribute to antidepressant drug actions (Gassen et al, 2014; Gassen et al, 2015). Lastly, FKBP5 has been shown to synergize with Hsp90 to block degradation of tau, contributing to accumulation of pathogenic tau species in the brain and to Alzheimer-type pathology (Blair et al, 2013).

The constant interplay of these processes gives rise to a complex network of FKBP5-modulated intracellular events. The specific pattern of this intracellular crosstalk may vary across tissues and may contribute to the pleiotropic consequences of FKBP5 dysregulation. 


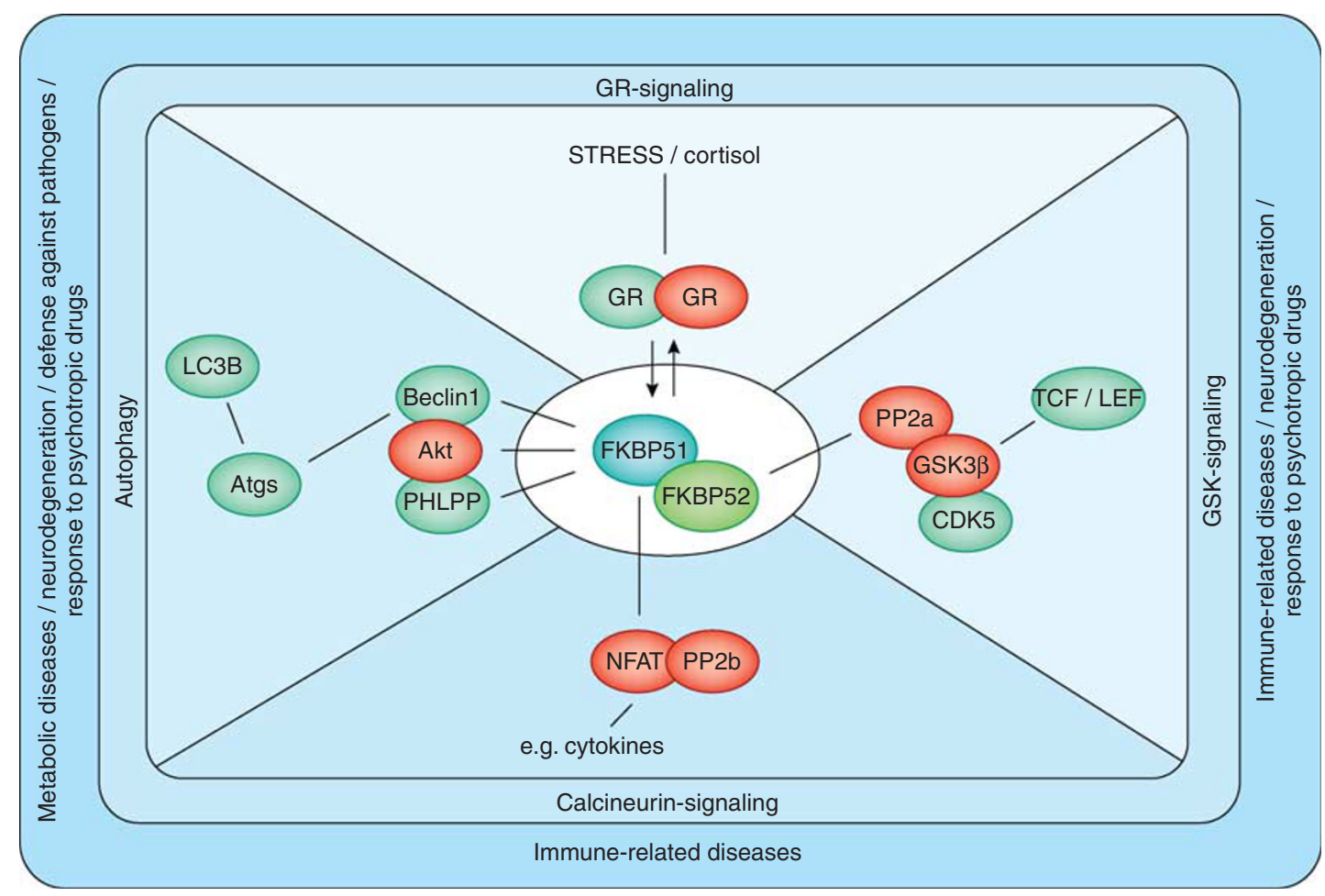

Figure 2. Selected interactions of FKBP51/FKBP5 and their impact on molecular processes. As discussed in the text, FKBP51 exerts an inhibitory effect on GR function, thus having a crucial role in stress physiology. FKBP51 further interacts with PHLPP, Akt, and Beclin1 and affects Akt/Beclin1-driven autophagy. As PHLPP dephosphorylates Akt at serine 473, inactive Akt is recruited to Beclin1, resulting in lower inhibitory phosphorylation of Beclin1 and thus the induction of autophagic pathways. Impact on autophagy might be a link of FKBP51 with diseases characterized by defective autophagy, including neurodegeneration, inflammatory diseases, and aging. FKBP51 further interacts with CDK5 and PP2A resulting in inhibition of GSK3 $\beta$ and activation of promoters targeted by the transcription factors TCF/LEF. FKBP51 shows high affinity to calcineurin (PP2b), and high levels of FKBP51 result in inhibition of PP2b-directed NFAT-signaling, thus affecting T-cell proliferation and function. Green color represents activation and red color represents inhibition by FKBP51.

\section{GENE-STRESS-EPIGENETIC REGULATION OF FKBP5}

\section{FKBP5 Gene Regulation}

The FKBP5 gene is located on the short arm of chromosome 6 (6p21.31), spans around $155 \mathrm{~kb}$, and consists of 13 exons (Figure 3). FKBP5 transcription is induced not only by GR but also by AR and PR activation (Hubler et al, 2003; Hubler and Scammell, 2004; Magee et al, 2006; U et al, 2004). GR-induced transcription is mediated by binding of the GR to GREs, which are located in a region spanning over $100 \mathrm{~kb}$ and range from upstream of FKBP5 promoter to introns 2, 5, and 7 of the gene (Paakinaho et al, 2010). These enhancer elements promote transcription via the formation of threedimensional (3D) chromatin loops and by coming into direct contact with the transcription start site and RNA polymerase II (Jaaskelainen et al, 2011; Klengel et al, 2013b). Active epigenetic marks, such as histone $\mathrm{H} 3$ lysine 4 methylation, lysine 27 acetylation, and lysine 36 trimethylation, indicate that at least in some tissues the locus conformation is already open before induction by steroids (Jaaskelainen et al, 2011).

FKBP5 is expressed at baseline and shows robust induction by GR across several tissues and species, but expression patterns show substantial variability. At baseline, in both humans and mice, FKBP5 expression levels differ across tissues, being markedly elevated in metabolically active tissues, such as adipocytes, and higher in $\mathrm{T}$ cells as compared with other peripheral blood cell types (http://biogps.org/). In humans, an over eightfold increase in FKBP5 mRNA has been observed in peripheral blood cells $3 \mathrm{~h}$ after oral administration of $1.5 \mathrm{mg}$ of the GR agonist dexamethasone, and $F K B P 5$ is in fact the most robustly induced transcript followed by IL1R2, ZBTB16, ECHDC3, and DDIT4 (Menke et al, 2012). Similar robust induction by GR activation has been noted in omental and subcutaneous adipose tissues (Pereira et al, 2014). However, FKBP5 induction can vary across individuals and has been proposed as a marker of GR sensitivity (Kelly et al, 2012; Menke et al, 2012; Vermeer et al, 2003). In the rodent brain, FKBP5 has the highest expression levels in the hippocampus, with much lower expression in other brain regions (Scharf et al, 2011). Substantial variability of FKBP5 expression is similarly observed in the human brain, with high levels noted, for example, in the hippocampus but low levels in the hypothalamus (http://human. brain-map.org/). Following stimulation with dexamethasone or stress exposure, FKBP5 expression is dramatically increased in a number of brain regions (Scharf et al, 2011), with the largest changes observed in the amygdala and the 


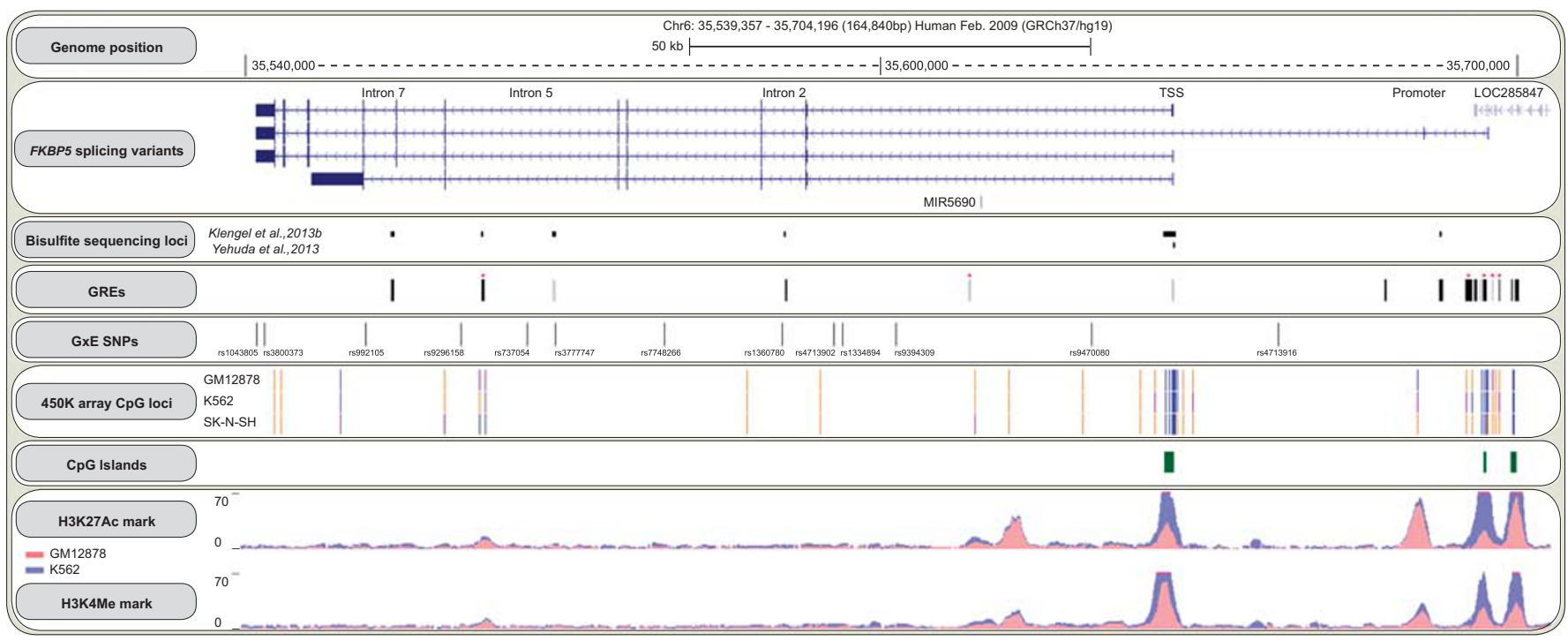

Figure 3. Schematic overview of key features of the FKBP5 locus. Shown tracks are from the UCSC genome browser (https://genome.ucsc.edu). FKBP5 splicing variants are derived from the RefSeq Genes Track. Bisulfite sequencing loci are shown as a custom track and are based on Klengel et al (2013b) and Yehuda et al (2013). As shown, these CpG sites are distinct from CpGs covered by the lllumina 450K array (shown for two blood cell lines and one neuroblastoma cell line based on ENCODE/HAIB; warm colors, high methylation; cold colors, low methylation levels). Glucocorticoid response elements (GREs) are displayed for A549 and ECC-1 cells and are derived from transcription factor (glucocorticoid receptor) ChIP-sequencing data of the ENCODE project. Conserved GREs are highlighted with red asterisk and are derived from the HMR Conserved Transcription Factor Binding Sites track (z-score cutoff: 1.64). GxE SNPs represent SNPs identified in gene-environment interaction studies and are mapped based on the Common SNPs(142) track (see also Table 1). The H3K27Ac Mark and H3K4Me3 tracks show data from two different blood cells lines derived from the ENCODE project.

PVN, whereas the hippocampus shows a much less pronounced FKBP5 induction. This likely reflects the high baseline levels of FKBP5 in this brain region that may confer relative GR resistance. FKBP5 expression can also be influenced by other factors. For example, FKBP5 expression increases with age in many regions of the mouse brain, including the hippocampus and cortical and subcortical structures (Jinwal et al, 2010). In humans, increases in the hippocampus, postcentral gyrus, superior frontal gyrus, and entorhinal cortex have been documented (Blair et al, 2013; Jinwal et al, 2010). Changes in FKBP5 mRNA levels have also been reported in peripheral blood cells across the menstrual cycle, with lower levels observed during the follicular phase of the cycle (Kinouchi et al, 2008).

The tissue- and context-specific FKBP5 expression should be taken into account when examining the consequences of FKBP5 dysregulation and when considering FKBP5 as candidate therapeutic target. Tissues with high baseline FKBP5 expression may be particularly amenable and susceptible to such interventions. On the other hand, tissues showing low baseline expression levels might be more relevant for dynamic regulation within the stress response. As we will discuss below, dynamic FKBP5 responses appear to be particularly relevant for gene-stress interactions and related outcomes.

\section{FKBP5 Genetic Variation}

With the use of tagging experiments and, more recently, next-generation sequencing, FKBP5 variants have been described in detail (Ellsworth et al, 2013a; Ellsworth et al, 2013b; Pelleymounter et al, 2011) (Figure 2). The bestcharacterized polymorphisms comprise a haplotype that spans the whole gene, contains up to 18 single-nucleotide polymorphisms (SNPs) in strong linkage disequilibrium in Caucasians $\left(r^{2}>0.8\right.$, distance $>500 \mathrm{~kb}, 1000$ genomes nextgeneration sequencing project), and is commonly tagged by rs3800373, rs9296158, or rs1360780. This haplotype has been associated with heightened induction of FKBP5 mRNA in response to GR activation (Binder et al, 2004).

This functionality was shown to be likely conferred by rs1360780, a SNP located in an enhancer region, 488 bp away from a functional GRE in intron 2 of the gene, with the rarer $T$ allele facilitating GR-mediated induction of FKBP5 mRNA (Klengel et al, 2013b). As shown by chromatin conformation capture experiments in lymphoblastoid cell lines, $\mathrm{T}$ allele is associated with a chromatin $3 \mathrm{D}$ conformation that promotes direct contact of the intron $2 \mathrm{GRE}$ with the transcription start site. This change in conformation is likely supported by the ability of the sequence containing the $\mathrm{T}$ allele to bind TATA-box binding protein, a protein shown to bring long range enhancer elements in contact with the transcriptional machinery (Bertolino and Singh, 2002), with significantly higher affinity than the alternate $\mathrm{C}$ allele (Klengel et al, 2013b). Consequently, $\mathrm{T}$ allele is associated with alteration of the ultra-short FKBP5-mediated feedback inhibition of the GR, especially during the stress recovery period (Zannas and Binder, 2014a). However, other polymorphisms within or outside of this FKBP5 haplotype may also have functional 
effects, either at baseline or following transcriptional induction (Ellsworth et al, 2013a).

Overall, the rs1360780 $\mathrm{T}$ allele, and related haplotypes, is associated with an increase in GR-induced FKBP5 upregulation. This then leads to a more dynamic FKBP5-mediated intracellular inhibition of GR that interferes with GRdependent feedback of the HPA axis on the systemic level and can contribute to HPA axis dysregulation and stressrelated phenotypes. This has been supported by studies showing prolonged cortisol responses and self-reported anxiety symptoms in $\mathrm{T}$ allele carrying healthy adults and adolescents after exposure to psychosocial stressors (Buchmann et al, 2014; Hohne et al, 2014; Ising et al, 2008) and increased cortisol levels in infants carrying the $\mathrm{T}$ allele following exposure to a female stranger coupled with brief parental separation (Luijk et al, 2010). In line with these findings, $\mathrm{T}$ allele has been associated with non-suppression of the HPA axis in healthy adults, as measured with the dexamethasone suppression (DST) and the dexamethasone-corticotropin releasing hormone (Dex-CRH) tests (Binder et al, 2008; Touma et al, 2011). Similar non-suppression of the HPA axis has been shown in MDD patients with the $T$ allele, who show less suppression of the HPA axis in the DST paradigm and less FKBP5 mRNA induction in peripheral blood (Menke et al, 2013). However, the effects of FKBP5 genotype on the HPA axis have been shown to vary across age groups, with aged, but not young, T-allele carriers showing suppressed cortisol responses following the Dex-CRH test in one study (Fujii et al, 2014a). Opposite effects of the T-allele in a low-dose dexamethasone suppression test have been observed with PTSD (Mehta, 2011). Here, the T allele was associated with GR super-suppression in PTSD, while hypocortisolism was seen in PTSD patients carrying the other genotype. Although the mechanisms of this opposite effect on GR sensitivity in PTSD vs MDD are not clear, one could consider that hypocortisolism has been described as an adaptive response to heightened levels of stress (Fries et al, 2005). FKBP5 risk allele could thus be associated with maladaptive HPA axis responses, but the direction of these may vary depending on stress and disease context. Different endocrine profiles in PTSD depending on FKBP5 genotype status may also contribute to some controversial reports on increased GR sensitivity and hypocortisolism in this disorder (Sriram et al, 2012; Yehuda et al, 1990).

The $\mathrm{T}$ allele has also been associated with increased attention bias toward threat, threat- and fear-induced hippocampal activation, as well as alterations in hippocampal shape and amygdala volume (Fani et al, 2013; Holz et al, 2014; Pagliaccio et al, 2015). These findings suggest that the 'risk' haplotype contributes to neuroendocrine dysregulation and perturbations in brain circuitry that may predispose to the development of stress-related psychiatric disorders. Indeed, studies have linked this haplotype with increased risk for relapse and recurrent course of MDD and PTSD (Binder et al, 2004; Wilker et al, 2014), maladaptive personality traits and attitudes (Minelli et al, 2013; Shibuya et al, 2010; Suzuki et al, 2014), worse cognitive performance (Fujii et al, 2014b), and higher risk for bipolar disorder (Willour et al, 2009), but lower risk for substance dependence and less severe withdrawal syndromes (Huang et al, 2014; Jensen et al, 2014; Levran et al, 2014). However, the main effects of FKBP5 genotypes are generally not consistently replicated and none of the GWAS meta-analyses show strong signals for this genetic locus yet. More consistent are reports of $F K B P 5 \times$ specific environmental stress interactions altering the risk for psychiatric disorders.

\section{Gene-Stress Interactions Involving FKBP5}

An increasing number of studies have linked interactions between FKBP5 genotypes and stressors with diverse phenotypes (Table 1). Phenotypes examined to date include MDD or depressive symptoms (Appel et al, 2011; Dackis et al, 2012; Kohrt et al, 2015; VanZomeren-Dohm et al, 2015; Zimmermann et al, 2011), PTSD and related phenotypes (Binder et al, 2008; Boscarino et al, 2012; Klengel and Binder, 2013a; Koenen et al, 2005; Xie et al, 2010), suicidality (Roy et al, 2010; Roy et al, 2012), aggression and violent behaviors (Bevilacqua et al, 2012), psychosis (Collip et al, 2013), cognitive performance (Hernaus et al, 2014), and general physical illness (Lessard and Holman, 2014). In 14 of these 18 study samples, equalling a total of 12000 subjects, the alleles associated with higher FKBP5 induction and prolonged cortisol responses are also the alleles associated with higher risk for the disorders. Interestingly, the effect is observed in different ethnic groups, including African American, Nepalese, European American, and European, suggestive of a similar functional relevance of the tested polymorphisms across ethnicities (Table 1).

These positive findings, however, have to be viewed in the context of the absence of a formal meta-analysis, which may be more difficult to conduct owing to the diverse outcomes and differences in study design and environmental measures employed by published studies. It is also important to note that gene-environment interaction studies are fraught with a number of limitations, including the complex nature of potential confounders involved in such studies, their generally low power and specific statistical issues as well as publication bias (Almli et al, 2014; Dick et al, 2015; Keller, 2014; Kraft and Aschard, 2015; Munafo et al, 2014), that could lead to spurious findings. Despite these limitations and the relative uncertainty of statistical interactions, the findings from studies examining FKBP5-stress interactions could inform issues common to gene-environment interactions $(\mathrm{G} \times \mathrm{E})$ studies in psychiatry as they extend the reported statistical interactions with experimental evidence for potential molecular and systemic mechanisms.

First, these studies suggest that the same 'risk' genotypes may lead to diverse phenotypes following exposure to similar stressors. As discussed above, stressors have been linked with a multitude of phenotypes, ranging from PTSD, MDD, and cognitive disorders to cardiovascular disease, cancer, and immune disorders (Cohen et al, 2007; Kaltsas et al, 2012; 
TABLE 1 Human Studies Examining Interactions Between Stress and FKBP5 Genotype on Psychiatric and Other Phenotypes and Related Endophenotypes

\begin{tabular}{|c|c|c|c|c|c|c|c|c|}
\hline Reference & Sample size & Ethnicity (\%) & Outcome (instrument) & $\begin{array}{l}\text { Stress measure/ } \\
\text { paradigm }\end{array}$ & SNP examined & Risk allele & $p$-Value & Primary study findings \\
\hline \multicolumn{9}{|c|}{ Major depression and depressive symptoms } \\
\hline Appel et al (2011) & 2144 & Caucasian & Depression (BDI-II) & CTQ & rs|360780 & $\mathrm{T}$ & $p=0.006$ & $\begin{array}{l}\text { The T allele interacted with } \\
\text { childhood abuse to increase MDD } \\
\text { risk }\end{array}$ \\
\hline $\begin{array}{l}\text { Zimmermann et al } \\
\text { (20lI) }\end{array}$ & $\begin{array}{l}884 \text { (discovery sample), } \\
1037 \text { (Dunedin study } \\
\text { replication sample), and } \\
\text { III6 (E-Risk study } \\
\text { replication sample) }\end{array}$ & $\begin{array}{c}\text { All subjects Caucasian in } \\
\text { the discovery sample and } \\
>90 \% \text { Caucasian in the } \\
\text { replication samples }\end{array}$ & $\begin{array}{l}\text { Depressive episodes } \\
\text { (M-CIDI) }\end{array}$ & $\mathrm{M}-\mathrm{CIDI}$ & $\begin{array}{l}\text { rs } 3800373 \\
\text { rs } 9296158 \\
\text { rs } 1360780 \\
\text { rs } 9470080 \\
\text { rs } 4713916\end{array}$ & $\begin{array}{l}\mathrm{C} \\
\mathrm{A} \\
\mathrm{T} \\
\mathrm{T} \\
\mathrm{A}\end{array}$ & $p<0.05$ & $\begin{array}{l}\text { In the discovery sample, risk alleles } \\
\text { interacted with lifetime trauma to } \\
\text { predict the higher risk for MDD. } \\
\text { Similar interaction was observed } \\
\text { with childhood trauma for } \\
\text { rs } 1360780 \text { in the E-Risk but not the } \\
\text { Dunedin sample }\end{array}$ \\
\hline Dackis et al (2012) & 236 & $\begin{array}{l}\text { African American (53.8) } \\
\text { Caucasian (33.9) } \\
\text { Hispanic (8.5) } \\
\text { Other (3.8) }\end{array}$ & $\begin{array}{l}\text { Depression (BDI-II) } \\
\text { Dissociation (DES) } \\
\text { Limbic irritability } \\
\text { (LSCL-33) }\end{array}$ & CTQ & $\begin{array}{l}\text { rs3800373 } \\
\text { rs9296158 } \\
\text { rs1360780 } \\
\text { rs9470080 }\end{array}$ & $\begin{array}{l}C \\
A \\
T \\
T\end{array}$ & $p<0.05$ & $\begin{array}{l}\text { The risk haplotype interacts with } \\
\text { childhood trauma having direct } \\
\text { effects on limbic irritability and } \\
\text { indirect effects on depression and } \\
\text { dissociation }\end{array}$ \\
\hline $\begin{array}{l}\text { VanZomeren- } \\
\text { Dohm et al (2015) }\end{array}$ & 489 & - & $\begin{array}{l}\text { Depressive symptoms } \\
\text { (MacArthur Health and } \\
\text { Behavior Questionnaire) }\end{array}$ & $\begin{array}{l}\text { MacArthur Health } \\
\text { and Behavior } \\
\text { Questionnaire }\end{array}$ & rs|360780 & - & $P<0.05$ & $\begin{array}{l}\text { FKBP5 genotype interacts with peer } \\
\text { victimization and child sex to shape } \\
\text { risk for depressive symptoms }\end{array}$ \\
\hline Kohrt et al (2015) & 682 & $\begin{array}{c}\text { Brahman (I6.1) } \\
\text { Chhetri (63.2) } \\
\text { Dalit/Nepali (17.4) } \\
\text { Janajati (3.2) }\end{array}$ & $\begin{array}{l}\text { Depressive symptoms } \\
\text { (BDI) } \\
\text { PTSD (PCL-C) }\end{array}$ & CTQ TEI SLERS & $\begin{array}{l}\text { rs9296I58 } \\
\text { rs1360780 } \\
\text { rs3800373 } \\
\text { rs9470080 }\end{array}$ & $\begin{array}{l}\text { A } \\
- \\
-\end{array}$ & $p=0.022$ & $\begin{array}{l}\text { The risk genotype interacts with } \\
\text { childhood maltreatment to predict } \\
\text { depressive symptoms but not PTSD }\end{array}$ \\
\hline \multicolumn{9}{|c|}{ Posttraumatic stress disorder, posttraumatic growth, and related phenotypes } \\
\hline Koenen et al (2005) & 46 & $\begin{array}{l}\text { African American (52.2) } \\
\text { Caucasian (47.8) }\end{array}$ & $\begin{array}{l}\text { PDEQ } \\
\text { PTSD-RI }\end{array}$ & $\begin{array}{l}\text { Medical injury } \\
\text { severity scores }\end{array}$ & $\begin{array}{l}\text { rs } 3800373 \\
\text { rs } 1360780\end{array}$ & $\begin{array}{l}C \\
T\end{array}$ & $p<0.05$ & $\begin{array}{l}\text { Risk alleles increase risk for } \\
\text { peritraumatic dissociation in } \\
\text { medically injured children }\end{array}$ \\
\hline Binder et al (2008) & 762 & $\begin{array}{l}\text { African American (95.2) } \\
\text { Caucasian (2.2) } \\
\text { Hispanic (0.6) } \\
\text { Asian (0.1) } \\
\text { Mixed (0.9) } \\
\text { Other (1.0) }\end{array}$ & $\begin{array}{l}\text { PTSD diagnosis (CAPS) } \\
\text { and severity (mPSS), } \\
\text { Depression (BDI) }\end{array}$ & CTQTEI & $\begin{array}{c}\text { rs3800373 } \\
\text { rs } 992105 \\
\text { rs } 9296158 \\
\text { rs737054 } \\
\text { rs|360780 } \\
\text { rs|334894 } \\
\text { rs9470080 } \\
\text { rs4713916 }\end{array}$ & $\begin{array}{l}\frac{C}{A} \\
\frac{T}{T} \\
\frac{T}{T}\end{array}$ & $\begin{array}{c}p<0.002 \\
p<\overline{0.001} \\
p<\overline{0.002} \\
p<\overline{0.002} \\
-\end{array}$ & $\begin{array}{l}\text { Risk alleles interacted with } \\
\text { childhood but not adulthood } \\
\text { trauma to predict greater PTSD } \\
\text { symptomatology }\end{array}$ \\
\hline Xie et al (2010) & 2427 & $\begin{array}{l}\text { African American (52.9) } \\
\text { Caucasian (47.1) }\end{array}$ & $\begin{array}{l}\text { PTSD diagnosis } \\
\text { (SSADDA) }\end{array}$ & SSADDA & $\begin{array}{l}\text { rs3800373 } \\
\text { rs9296158 } \\
\text { rs } 1360780 \\
\text { rs9470080 }\end{array}$ & $\frac{-}{\bar{T}}$ & $p=\frac{\bar{Z}}{\bar{Z}}$ & $\begin{array}{l}\text { rs } 9470080 \text { T-allele African } \\
\text { American homozygotes had higher } \\
\text { risk for PTSD if exposed to early } \\
\text { trauma but lower risk if not exposed }\end{array}$ \\
\hline $\begin{array}{l}\text { Boscarino et al } \\
(20 / 2)\end{array}$ & 410 & Caucasian & $\begin{array}{l}\text { Lifetime and early-onset } \\
\text { PTSD }\end{array}$ & ACES & rs9470080 & $\mathrm{T}$ & $\begin{array}{c}p=0.026 \\
\text { (lifetime PTSD) } \\
p=0.016 \\
\text { (early-onset } \\
\text { PTSD }\end{array}$ & $\begin{array}{l}\text { The } T \text { allele confers risk that } \\
\text { interacts with other genes and early } \\
\text { trauma to predict PTSD risk }\end{array}$ \\
\hline Klengel et al (2013) & 1963 & African American & PTSD (PSS, CAPS) & $\begin{array}{l}\text { CTQ } \\
\text { TEI }\end{array}$ & rs/360780 & $\mathrm{T}$ & $\begin{array}{c}p=0.012 \\
\text { (current PTSD } \\
\text { symptoms) } \\
p<0.001 \\
\text { (lifetime PTSD) }\end{array}$ & $\begin{array}{l}\text { The T allele interacted with } \\
\text { childhood maltreatment to predict } \\
\text { increased current PTSD } \\
\text { symptomatology and higher risk for } \\
\text { lifetime PTSD }\end{array}$ \\
\hline Dunn et al (2014) & 204 & $\begin{array}{c}\text { Non-Hispanic African } \\
\text { American }\end{array}$ & $\begin{array}{l}\text { PTSD } \\
\text { PTG }\end{array}$ & $\begin{array}{l}\text { Severity of exposure } \\
\text { to the hurricane } \\
\text { Katrina }\end{array}$ & $\begin{array}{l}\text { rs } 1360780 \\
\text { rs } 9296158 \\
\text { rs } 9470080\end{array}$ & $\frac{c}{-}$ & $\begin{array}{c}p=0.011 \text { but } \\
\text { non-significant } \\
\text { after correction } \\
\text { for multiple } \\
\text { testing }\end{array}$ & $\begin{array}{l}\text { FKBP5 rs } 1360780 \\
\text { T-allele carriers experienced greater } \\
\text { PTG following exposure to the } \\
\text { hurricane Katrina }\end{array}$ \\
\hline
\end{tabular}

Suicide attempts

\begin{tabular}{|c|c|c|c|c|c|}
\hline Roy et al $(2010)$ & 427 & African American & Suicide attempt & CTQ & $\begin{array}{l}\text { rs } 3800373 \\
\text { rs } 9296158 \\
\text { rs } 1360780 \\
\text { rs } 9470080 \\
\text { rs } 4713902 \\
\text { rs3777747 }\end{array}$ \\
\hline Roy et al (2012) & 474 & African American & Suicide attempts & CTQ & rs3800373 \\
\hline
\end{tabular}

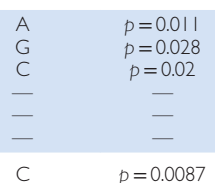

Risk genotypes interacted with childhood trauma to confer risk for suicide attempts

The risk allele had an additive effect with $C R H B P$ genotype on risk for suicide attempts in individuals exposed to high early traum

Aggression and violent behaviors

\begin{tabular}{|c|c|c|c|c|c|c|c|c|}
\hline $\begin{array}{l}\text { Bevilacqua et al } \\
(20 \mid 2)\end{array}$ & 411 & Caucasian & $\begin{array}{l}\text { Aggression (BGHA) } \\
\text { Hostility (BDHI) } \\
\text { Impulsiveness (BIS) } \\
\text { Violence (prison records) }\end{array}$ & CTQ & $\begin{array}{l}\text { rs3800373 } \\
\text { rs9296I58 } \\
\text { rs1360780 } \\
\text { rs9470080 }\end{array}$ & $\begin{array}{l}C \\
A \\
T \\
T\end{array}$ & $\begin{array}{l}p=0.017 \\
p=0.08 \\
p=0.015 \\
p=0.043\end{array}$ & $\begin{array}{l}\text { Risk genotypes interacted with early } \\
\text { trauma to increase risk for } \\
\text { aggression scores and reported } \\
\text { violence }\end{array}$ \\
\hline \multicolumn{9}{|l|}{ Psychosis } \\
\hline Collip et al (20|3) & 401 & Caucasian & CAPE & CTQ & $\begin{array}{l}\text { rs9296158 } \\
\text { rs|360780 } \\
\text { rs } 1043805 \\
\text { rs4713916 }\end{array}$ & $\begin{array}{l}\mathrm{A} \\
\mathrm{T} \\
\mathrm{A} \\
\mathrm{A}\end{array}$ & $\begin{array}{l}p<0.01 \\
p<0.01 \\
p<0.001 \\
p=0.08\end{array}$ & $\begin{array}{l}\text { Risk alleles interacted with } \\
\text { childhood trauma to predispose to } \\
\text { psychotic symptoms }\end{array}$ \\
\hline
\end{tabular}


TABLE 1 (Continued)

\begin{tabular}{|c|c|c|c|c|c|c|c|c|}
\hline Reference & Sample size & Ethnicity (\%) & Outcome (instrument) & $\begin{array}{l}\text { Stress measure/ } \\
\text { paradigm }\end{array}$ & SNP examined & Risk allele & $p$-Value & Primary study findings \\
\hline \multicolumn{9}{|l|}{ Physical health } \\
\hline $\begin{array}{l}\text { Lessard and } \\
\text { Holman, 2014) }\end{array}$ & 527 & Caucasian & $\begin{array}{l}\text { Physical health (health } \\
\text { survey) }\end{array}$ & DIST & rs $\mid 360780$ & $\mathrm{~T}$ & $\begin{array}{l}p<0.001 \text { for } \\
\text { childhood } \\
\text { trauma } \\
p=0.006 \text { for } \\
\text { adulthood } \\
\text { stressors }\end{array}$ & $\begin{array}{l}\text { Only in T-allele carriers, childhood } \\
\text { trauma and adulthood stress to } \\
\text { predict worse physical health }\end{array}$ \\
\hline \multicolumn{9}{|c|}{ Neuroimaging and neuroendocrine endophenotypes } \\
\hline Luijk et al (20।0) & 589 infants & - & $\begin{array}{l}\text { Attachment behavior } \\
\text { Salivary cortisol before } \\
\text { and after stress exposure }\end{array}$ & $\begin{array}{l}\text { Strange Situation } \\
\text { Procedure }\end{array}$ & rs $\mid 360780$ & $\mathrm{~T}$ & $p=0.01$ & $\begin{array}{l}\text { T-allele camiers show stronger } \\
\text { cortisol reactivity in response to the } \\
\text { stress paradigm }\end{array}$ \\
\hline White et al (20|2) & 139 & Caucasian & $\begin{array}{l}\text { Amygdala reactivity } \\
\text { measured by } \mathrm{fMRI}\end{array}$ & CTQ & $\begin{array}{l}\text { rs3800373 } \\
\text { rs9296158 } \\
\text { rs } 1360780 \\
\text { rs9470080 } \\
\text { rs } 7748266 \\
\text { rs9394309 }\end{array}$ & $\begin{array}{l}G \\
A \\
T \\
T \\
T \\
G\end{array}$ & $\begin{array}{l}p=0.003 \\
p=0.002 \\
p=0.002 \\
p=0.011 \\
p=0.011 \\
p=0.097\end{array}$ & $\begin{array}{l}\text { Risk alleles interacted with } \\
\text { childhood emotional neglect to } \\
\text { predict greater dorsal amygdala } \\
\text { reactivity }\end{array}$ \\
\hline Hemaus et al (2014) & 184 & Caucasian & $\begin{array}{l}\text { Cognitive performance } \\
\text { Hippocampal volume }\end{array}$ & CTQ & $\begin{array}{l}\text { rs9296158 } \\
\text { rs4713916 } \\
\text { rs992105 } \\
\text { rs3800373 }\end{array}$ & $\begin{array}{l}- \\
- \\
-\end{array}$ & $\begin{array}{l}- \\
- \\
-\end{array}$ & $\begin{array}{l}\text { Childhood trauma did not interact } \\
\text { with FKBP5 and BDNF to predict } \\
\text { cognitive performance or } \\
\text { hippocampal volumes }\end{array}$ \\
\hline Hohne et al (2014) & 116 & Caucasian & $\begin{array}{l}\text { Childhood adverse events } \\
\text { (M-CIDI) } \\
\text { Acute depression } \\
\text { symptoms (BDI-II) } \\
\text { Change in plasma cortisol }\end{array}$ & $\begin{array}{l}\text { Change in plasma } \\
\text { cortisol after TSST }\end{array}$ & rs/360780 & $T$ & $p<0.05$ & $\begin{array}{l}\text { After exposure to psychosocial } \\
\text { stressors, adult and adolescent } \\
\text { healthy T-allele carriers showed } \\
\text { more robust and prolonged cortisol } \\
\text { responses and smaller changes in } \\
\text { FKBP5 mRNA }\end{array}$ \\
\hline $\begin{array}{l}\text { Pagliaccio et al } \\
(2014)\end{array}$ & 120 & $\begin{array}{c}\text { White } \\
(57.5) \\
\text { African American (30.0) } \\
\text { Other or mixed race } \\
(12.5)\end{array}$ & $\begin{array}{l}\text { PAPA } \\
\text { CAPA } \\
\text { Amygdala activity, } \\
\text { connectivity, volume } \\
\text { (fMRI) }\end{array}$ & $\begin{array}{l}\text { PAPA CAPA } \\
\text { Behavioral tasks }\end{array}$ & $\begin{array}{l}\text { rs } 1360780 \text { as part of } \\
\text { a polygenic score }\end{array}$ & $\mathrm{T}$ & $p=0.04$ & $\begin{array}{l}\text { Higher polygenic scores were } \\
\text { associated with smaller left but not } \\
\text { right amygdala and hippocampus } \\
\text { volumes in the context of low levels } \\
\text { of stressor exposure }\end{array}$ \\
\hline Holz et al (20|4) & 153 & Caucasian & $\begin{array}{l}\text { Amygdala activity, } \\
\text { connectivity, volume } \\
\text { (fMRI) } \\
\text { SCID-I } \\
\text { Substance use inventory } \\
\text { BDI }\end{array}$ & $\begin{array}{l}\text { CFA } \\
\text { CTQ }\end{array}$ & rs 1360780 & $T$ & $p=0.049$ & $\begin{array}{l}\text { Childhood emotional neglect } \\
\text { interacted with the T allele to } \\
\text { predict increased threat-related } \\
\text { activity in the right amygdala }\end{array}$ \\
\hline $\begin{array}{l}\text { Buchmann et al } \\
(20 \mid 4)\end{array}$ & 195 & - & Plasma cortisol & $\begin{array}{l}\text { CTQ } \\
\text { TSST } \\
\text { Family adversity } \\
\text { index measured by } \\
\text { parent interview }\end{array}$ & rs|360780 & $\mathrm{T}$ & $p<0.05$ & $\begin{array}{l}\text { T-allele carriers show more } \\
\text { pronounced cortisol responses to } \\
\text { TSST. Childhood maltreatment is } \\
\text { associated with lower cortisol levels } \\
\text { and faster cortisol recovery but only } \\
\text { in CC homozygotes. }\end{array}$ \\
\hline $\begin{array}{l}\text { Pagliaccio et al } \\
(2015)\end{array}$ & 107 & $\begin{array}{l}\text { African American } \\
\text { (37.4) } \\
\text { White } \\
(62.6)\end{array}$ & $\begin{array}{l}\text { Amygdala and } \\
\text { hippocampal activity } \\
\text { (fMRI) } \\
\text { PAPA } \\
\text { CAPA } \\
\text { Tanner Pubertal Staging } \\
\text { Questionnaire }\end{array}$ & $\begin{array}{l}\text { PAPA } \\
\text { CAPA } \\
\text { Facial emotion } \\
\text { processing task }\end{array}$ & $\begin{array}{l}\text { rs } 1360780 \text { as part of } \\
\text { a polygenic score } \\
\text { comprised of } 10 \\
\text { SNPs within CRHRI, } \\
\text { NR3C2, NR3CI, and } \\
\text { FKBP5 }\end{array}$ & $T$ & $\begin{array}{l}p=0.037 \text { but } \\
\text { non-significant } \\
\text { after correction } \\
\text { for multiple } \\
\text { testing }\end{array}$ & $\begin{array}{l}\text { Life events interacted with polygenic } \\
\text { score to predict left hippocampal } \\
\text { activity during the facial emotion } \\
\text { processing task }\end{array}$ \\
\hline
\end{tabular}

Abbreviations: ACES, adverse childhood experiences study scale; BDHI, Buss-Durkee hostility inventory; BDI, Beck depression inventory; BGHA, Brown-Goodwin lifetime history of aggression questionnaire; BIS, Barratt impulsiveness scale; BDNF, brain-derived neurotrophic factor; CAPA, child and adolescent psychiatric assessment; CAPE, community assessment of psychic experiences; CAPS, clinician administered PTSD scale; CFA, childhood family adversity; CRHBP, corticotropin releasing hormone binding protein; CTQ, child trauma questionnaire; DES, dissociative experiences scale; DIST, diagnostic interview schedule trauma section; fMRI, functional magnetic resonance imaging; LSCL-33, Limbic system checklist-33; PAPA, preschool age psychiatric assessment; PCL-C, PTSD checklist-civilian version; PDEQ, peritraumatic dissociative experiences questionnaire; PSS, PTSD symptom scale; PTG, posttraumatic growth; PTSD, posttraumatic stress disorder; PTSD-RI, PTSD reaction index; SLERS, stressful life events rating scale for cross cultural study (SLERS); SNP, single nucleotide polymorphism; SSADDA, semi-structured assessment for drug dependence and alcoholism; TEl, traumatic events inventory; TSST, Trier social stress test.

Kendler et al, 1999; Sinha, 2007; Tsolaki et al, 2009; van Winkel et al, 2008). Phenotypes are generally thought to emerge through complex interactions among genetic, developmental, and environmental factors, and their development has been hypothesized to be mediated by underlying risk endophenotypes that lie in closer etiopathogenic proximity to risk genotypes such as altered endocrine regulation (Gottesman and Gould, 2003; Zannas and West, 2014b). Such an endophenotype, characterized by stress vulnerability, could be conferred by 'risk' FKBP5 polymorphisms. This shared vulnerability may then contribute to the development of diverse phenotypes, depending on other genetic, developmental, and environmental factors. In the case of FKBP5, this differential vulnerability could be driven by brain region-specific effects. An important brain region associated with FKBP5-related risk is the amygdala. In this brain region, the knockdown of Fkbp5 in mice was shown to prevent stressor-induced increases in fear (Attwood et al, 2011), and two studies in humans have shown that FKBP5 variants interact with childhood adversity to predict threatinduced activity in this region (Holz et al, 2014; White et al, 2012). FKBP5 genotype was further shown to moderate, as part of a polygenic risk score comprised of selected HPA axis SNPs, stress-related structural and functional changes 
not only in the amygdala but also in the hippocampus in humans. Specifically, higher polygenic scores were associated with smaller left, but not right, amygdala and hippocampus volumes in the context of low levels of stressor exposure (Pagliaccio et al, 2014). The authors suggested that this atypical finding might be explained by an overriding effect of high levels of stress exposure on genetic influences. Brain region-specific effects of environmental stressors on FKBP5 pathways have also been observed in transgenic mice. For example, mice lacking the Fkbp5 gene show stress-induced decline in synapsin expression in the prefrontal cortex but not in the hippocampus (Schmidt et al, 2015). Understanding the brain region- but also cell type-specific effects of FKBP5 may offer valuable insights into the pathogenesis of stress-related conditions. In addition to such cell- and tissuespecific effects, differential sensitivity to effects of molecular partners of FKBP5 could also contribute to diverse symptom presentations. For example, the effects of FKBP5 dysregulation on $\mathrm{NF}-\kappa \mathrm{B}$ signaling in the periphery could contribute to proinflammatory conditions and cancer (Romano et al, 2004; Romano et al, 2010). Similarly, tumorigenic effects could be mediated by the consequences of FKBP5 dysregulation on Akt signaling (Pei et al, 2009).

Second, outcomes have been shown to depend on the timing of the trauma exposure. Several studies have consistently shown that early trauma exposure in carriers of the haplotype associated with higher FKBP5 mRNA induction increases the risk for psychiatric disorders in adulthood (Appel et al, 2011; Binder et al, 2008; Dackis et al, 2012; Lessard and Holman, 2014; Roy et al, 2010; Roy et al, 2012; Xie et al, 2010; Zimmermann et al, 2011). Although similar interactions have been observed in some studies with traumatic events occurring beyond childhood, in adolescence and early adulthood (Lessard and Holman, 2014; Zimmermann et al, 2011), other studies found that FKBP5-stress interactions are triggered only by childhood trauma (Binder et al, 2008; Klengel et al, 2013b) (Table 1). In a recent study in adolescents, FKBP5 genotype moderated the effects of current peer victimization but not early institutionalization before the age of 2 years (VanZomerenDohm et al, 2015). These time-dependent findings are in accordance with studies highlighting the role of stressor timing on neuroplasticity and risk for psychopathology (Gee and Casey, 2015). The exact role of stressor timing, type, and duration and the potential synergistic effect of multiple stressor exposures will need to be further delineated in longitudinal gene-environment interaction studies.

Finally, so-called FKBP5 risk alleles do not confer risk under all circumstances. The same alleles have also been associated with PTG, for example, following exposure to the Hurricane Katrina (Dunn et al, 2014), as well as less depression in the context of early institutionalization but low current stress (VanZomeren-Dohm et al, 2015) and less lifetime PTSD in the absence of child abuse in a highly traumatized cohort (Klengel et al, 2013b). Furthermore, in some, but not all studies, the FKBP5 allele associated with stronger mRNA induction has also been associated with a favorable response to antidepressant drug treatment (Binder et al, 2004; Zou et al, 2010), while a worse response to psychotherapy was reported for PTSD patients carrying the risk allele (Wilker et al, 2014). As previously discussed, these heterogeneous outcomes raise the possibility that what such alleles may confer is increased plasticity, with opposite outcomes being then possible depending on the presence of positive or negative environmental influences (Belsky and Hartman, 2014; Belsky et al, 2009; Belsky and Pluess, 2013). Yet the exact role of timing, type and duration of these genotype-dependent environmental challenges and the molecular and cellular mechanisms underlying such differential outcomes remain to be elucidated by future studies.

\section{Epigenetic Regulation of FKBP5 and a Potential Role in Mediating Gene-Stress Interactions}

An important mechanism that mediates lasting environmental effects on gene function occurs at the level of epigenetic regulation of gene transcription (Feil and Fraga, 2011; Telese et al, 2013). Epigenetic changes consist of a number of biochemical processes, including DNA methylation and hydroxymethylation, posttranslational histone modifications, and non-coding RNAs. Among these, DNA methylation is the most established lasting epigenetic modification induced by early life stressor exposure (Franklin et al, 2010; Weaver et al, 2004; Zannas and West, 2014b). Importantly, DNA methylation changes have been shown to occur in an allele-specific manner (Meaburn et al, 2010), suggesting that epigenetic changes induced by stressors may also depend on genetic context.

In light of these facts, a plausible question is whether allelespecific DNA methylation changes may mediate the interaction between childhood abuse and FKBP5. In fact, in rs1360780 $\mathrm{T}$ allele carriers, but not individuals with the alternate genotype, exposure to childhood abuse was shown to be associated with lower methylation of $\mathrm{CpG}$ sites located near the functional FKBP5 intron 7 GRE in DNA from peripheral blood cells (Klengel and Binder, 2013a; Klengel and Binder, 2015). Reporter gene assays showed that decreased methylation in this region is associated with disinhibited GR-induced transcription of FKBP5 and GR resistance as revealed in ex vivo assays of GR sensitivity (Klengel et al, 2013b). This reduced methylation was observed specifically with exposure to childhood but not adult trauma and did not correlate with current plasma cortisol levels. Previous studies have shown that GR binding to GREs can induce CpG demethylation, and this demethylation can lead to de-repressed transcriptional responses to subsequent glucocorticoid exposure (Thomassin et al, 2001); thus we hypothesize that early trauma in FKBP5 risk allele carriers leads to enhanced GR activation and demethylation of FKBP5 GREs, and to further disinhibition of FKBP5 transcriptional regulation and GR resistance, selectively in $\mathrm{T}$ allele carriers (Figure 1). To test this hypothesis, human hippocampal precursors (Anacker et al, 2011) were treated with dexamethasone, a selective GR agonist, at several 
differentiation stages. Dexamethasone exposure during proliferation and early differentiation induced demethylation of the same CpGs in intron 7 of the FKBP5 gene that shows reduced methylation with early trauma. In fact, these three CpGs are located within or between the three predicted consensus GRE sites in this locus, while the ones not affected are located upstream. This further suggests a direct causal effect of GR activation in this demethylation. This demethylation was stable to a 20-day washout when the cells were treated during differentiation but not in cells treated after differentiation. Taken together, these data support a developmentally restricted effect of early trauma and glucocorticoid exposure on selective FKBP5 methylation sites that appears to occur across peripheral and neuronal tissues and to depend on susceptible FKBP5 variants. The molecular mechanisms associated with the differential epigenetic effects depending on developmental stage have not yet been elucidated, but strong developmental regulation has been reported for several epigenetic readers and writers (Lv et al, 2013).

Notably, FKBP5 methylation changes have been observed but may also vary across species and in different environmental contexts. In mice, Fkbp5 demethylation is induced by systemic glucocorticoid exposure in the hippocampus, hypothalamus, and peripheral blood (Lee et al, 2010). However, the mouse glucocorticoid-susceptible CpGs are located not in intron 7 , as in humans, but in intron 1 of the gene. On the other hand, CpG sites located within intron 5 of Fkbp5 have been shown to be demethylated with aging in mice (Sabbagh et al, 2014). Aging has also been shown to accelerate FKBP5 demethylation in several regions in the human brain, but this effect was observed in intron 7 and promoter region of the gene (Blair et al, 2013). These species-specific differences in the epigenetic regulation of FKBP5 across species are supported by data showing that only GREs located within the introns 1 and 5 of the gene are conserved across mice, rats, and humans (Figure 2). It will be important to further elucidate the species- and context-specific pattern of epigenetic modifications in FKBP5 to promote translatability and potential utility of these modifications as biomarkers of distinct stress phenotypes.

The mechanisms underlying these changes in DNA methylation levels remain poorly understood. Active DNA demethylation through receptor-mediated processes is a plausible mechanism (Kress et al, 2006; Nelson et al, 2008), but the potential involvement of active demethylation and hydroxymethylation as intermediate step and how this may be targeted to selective CpGs has not been examined. An additional contributing mechanism may be the downregulation of DNA methyltransferase 1 (Yang et al, 2012). Uncovering the molecular events that underlie stressor-induced epigenetic modifications of FKBP5 could offer the opportunity to understand mechanisms that may allow reversal of these molecular processes and the consequent phenotypes.

\section{FKBP5 DISINHIBITION: CLINICAL AND TRANSLATIONAL IMPLICATIONS}

Several lines of evidence suggest that FKBP5 disinhibition may, in many cases, predispose an individual to the development of pathological phenotypes. This was initially supported by gene-environment interaction studies showing that the haplotype associated with higher FKBP5 mRNA induction confers vulnerability to the development of stress-related psychiatric disorders following traumatic exposure (Table 1). More recently, postmortem studies have found FKBP5 overexpression in several brain regions in association with Alzheimer's disease and schizophrenia (Blair et al, 2013; Sinclair et al, 2013). Although postmortem investigations offer the advantage of examining FKBP5 levels in brain tissue, they also have the caveat of not accounting for confounding factors, such as stressor exposure or cortisol levels, which may drive and thus confound the putative differences in FKBP5 levels between cases and controls. Beyond psychiatric phenotypes, FKBP5 disinhibition has also been implicated in a multitude of other medical conditions, including poor glucocorticoid responses in asthma (Stechschulte and Sanchez, 2011; Woodruff et al, 2007), insulin resistance in metabolically active tissues (Pereira et al, 2014), and immune dysregulation that may contribute to the pathogenesis of melanoma and other cancer types (Kim et al, 2012; Romano et al, 2004; Romano et al, 2010). Taken together, these lines of evidence support a model where FKBP5 disinhibition may represent a stress-sensitive endophenotype for a number of disease phenotypes.

These human studies have been corroborated by studies in animal models. Given the current lack of humanized Fkbp5 transgenic mice, animal studies to date have either examined conventional Fkbp5 knockouts (KO) or conditional Fkbp5 knockdown. Compared with wild-type mice, Fkbp5 KOs generally exhibit a more resilient phenotype, characterized by lower corticosterone levels and improved sleep architecture and behavioral responses following restraint, forced swim, and social defeat stress, as well as enhanced cognitive flexibility in the radial arm water maze (Albu et al, 2014; Hartmann et al, 2012; O'Leary et al, 2011; Sabbagh et al, 2014; Touma et al, 2011). However, to mechanistically dissect the role of $F k b p 5$ disinhibition in stress-related phenotypes, it will be important to examine its possibly distinct role in different brain regions. For example, selective Fkbp5 silencing in the amygdala was shown to confer resilience to restraint stress exposure (Attwood et al, 2011). Higher levels of hypothalamic Fkbp5 expression were related to increased body weight gain in mice on high-fat diet (Balsevich et al, 2014), suggesting additional brain region-specific links to peripheral metabolic phenotypes beyond downstream activation of immune pathways.

These observations spurred efforts to develop drugs that block FKBP5 activity. Until recently, such efforts had been hindered by their non-selective binding to other FKBPs, 
most importantly FKBP4 (Gaali et al, 2011), which, as we discussed above, has opposite effects on GR signaling (Figure 1). To overcome this issue, highly selective FKBP5 ligands (SAFit) were recently developed, based on an induced-fit mechanism. These compounds were shown to stimulate neurite outgrowth in primary hippocampal neurons and to promote homeostasis of the HPA axis and stress-coping behaviors in mice (Gaali et al, 2015). Although these findings are encouraging, the precise cellular and molecular mechanisms that underlie SAFit activity remain unknown. In particular, it will be critical to elucidate which molecular interactions of FKBP5 and, consequently, which cellular processes are differentially affected by SAFit in different cell types, regions, and organisms. For example, FKBP5 inhibitors block the interaction with the GR but not the Akt pathway (Fabian et al, 2013). A more detailed assessment of differential effects of downstream partners will need to be performed to assess the optimal combination of blocked downstream target for specific disease phenotypes. Finally, in certain cases and selective tissues, FKBP5 upregulation may represent an adaptive and desirable response to heightened levels of stress, and in such cases FKBP5 blockade could lead to adverse consequences. This is suggested, for example, by studies showing that highinduction FKBP5 alleles may be associated with favorable antidepressant responses (Binder et al, 2004; Zou et al, 2010) and that FKBP5 can promote antidepressant activity (Gassen et al, 2014; Gassen et al, 2015). These questions related to potency, mechanism, and safety of SAFit remain to be examined and extended to humans.

\section{CONCLUSIONS AND FUTURE DIRECTIONS}

Since the discovery of FKBP5 20 years ago (Baughman et al, 1995), converging evidence from human and animal studies has advanced our understanding into how gene-stress-epigenetic interactions may regulate FKBP5 responsivity, and how FKBP5 disinhibition may contribute to stress-related phenotypes, thus serving as potential therapeutic target (O'Leary et al, 2011; Schmidt et al, 2012). Below we discuss remaining open questions and potential future directions for this line of research.

First, can we infer strategies for stress-disorder biomarker research from the example of FKBP5? As we discussed, complex phenotypes are likely shaped by the effects of genestress-epigenetic interactions on tissues that are involved in disease pathogenesis. Given the inherent limitations of examining such tissues, for example, brain in living humans, it is essential to identify peripheral markers that correlate with similar markers in the tissues of interest. This is true for genetic polymorphisms but not for epigenetic modifications, which show substantial tissue specificity. Endeavors to identify biomarkers may benefit from the translation of findings from living human cohorts with detailed data on timing and type of stressor exposure to molecular findings from postmortem human studies and animal models. For instance, changes in Fkbp5 methylation in mouse blood have been suggested to be a promising biomarker that reflects chronic glucocorticoid exposure burden and similar changes in the brain (Ewald et al, 2014; Lee et al, 2011); similarly, glucocorticoid exposure affects methylation in a neuronal progenitor cell line of the same CpGs showing changes with early trauma in blood. However, it remains to be determined whether FKBP5 methylation levels also reflect the effects of chronic stress across tissues and whether this finding holds true in humans.

Second, can FKBP5 serve as a target for individualized treatment modalities? The development of SAFit has been an important step towards modulating phenotypes where FKBP5 disinhibition may be a contributing factor. A central question will be whether FKBP5 antagonism leads to symptom improvement only in patients with genetic and epigenetic changes associated with FKBP5 disinhibition or whether it could be beneficial to all patients showing similar symptoms. The use of biomarkers reflecting FKBP5 disinhibition, such as 'risk' FKBP5 polymorphisms or low FKBP5 methylation levels at CpG sites near functional GREs, may prove useful for guiding these studies. Furthermore, the timing of treatment initiation may be critical. Will inhibition of FKBP5 only be beneficial early in disease risk development, shortly after trauma exposure, when symptoms may not have fully developed, or will it also reduce symptoms once the disease has fully manifested? The first possibility may again require biomarkers of increased risk for efficient preventive strategies. In addition, different molecular interactions of FKBP5 may contribute to different phenotypes and these specific molecular events may need to be selectively targeted in order to maximize efficacy and safety, necessitating the development of even more specific antagonists. Finally, we will need to understand whether FKBP5 antagonists may be used as monotherapy $v s$ augmentation strategy in addition to established treatment, including psychotherapy.

Finally, while valuable lessons may be learned from the example of FKBP5, it is clear that risk for stress-related disorders is shaped by complex interactions among multiple environmental stressors and many genes with small individual effects on expressed phenotypes. Elucidating these interactions at a systems level is a daunting task but may contribute to a more holistic understanding of stress-related disorders.

\section{FUNDING AND DISCLOSURE}

This work was supported by an ERC starting grant to EBB and FP7 framework grant number 281338 (GxE molmech) and a Marie-Sklodowska Curie fellowship (H2020 grant no. 653240) to ASZ. EBB is co-inventor of the patent application 'FKBP5: a novel target for antidepressant therapy' (European Patent no. EP 1687443 B1). The other authors declare no conflict of interest. 


\section{REFERENCES}

Albu S, Romanowski CP, Letizia Curzi M, Jakubcakova V, Flachskamm C, Gassen NC et al (2014). Deficiency of FK506-binding protein (FKBP) 51 alters sleep architecture and recovery sleep responses to stress in mice. J Sleep Res 23: 176-185.

Almli LM, Duncan R, Feng H, Ghosh D, Binder EB, Bradley B et al (2014). Correcting systematic inflation in genetic association tests that consider interaction effects: application to a genome-wide association study of posttraumatic stress disorder. JAMA Psychiatry 71: 1392-1399.

Anacker C, Zunszain PA, Cattaneo A, Carvalho LA, Garabedian MJ, Thuret S et al (2011). Antidepressants increase human hippocampal neurogenesis by activating the glucocorticoid receptor. Mol Psychiatry 16: 738-750.

Appel K, Schwahn C, Mahler J, Schulz A, Spitzer C, Fenske K et al (2011). Moderation of adult depression by a polymorphism in the FKBP5 gene and childhood physical abuse in the general population. Neuropsychopharmacology 36: 1982-1991.

Attwood BK, Bourgognon JM, Patel S, Mucha M, Schiavon E, Skrzypiec AE et al (2011). Neuropsin cleaves EphB2 in the amygdala to control anxiety. Nature 473: 372-375.

Balsevich G, Uribe A, Wagner KV, Hartmann J, Santarelli S, Labermaier C et al (2014). Interplay between diet-induced obesity and chronic stress in mice: potential role of FKBP51. J Endocrinol 222: 15-26.

Bamberger CM, Schulte HM, Chrousos GP (1996). Molecular determinants of glucocorticoid receptor function and tissue sensitivity to glucocorticoids. Endocr Rev 17: 245-261.

Barent RL, Nair SC, Carr DC, Ruan Y, Rimerman RA, Fulton J et al (1998). Analysis of FKBP51/FKBP52 chimeras and mutants for Hsp90 binding and association with progesterone receptor complexes. Mol Endocrinol 12: 342-354.

Baughman G, Wiederrecht GJ, Campbell NF, Martin MM, Bourgeois S (1995). FKBP51, a novel T-cell-specific immunophilin capable of calcineurin inhibition. Mol Cell Biol 15: 4395-4402.

Belleville G, Marchand A, St-Hilaire MH, Martin M, Silva C (2012). PTSD and depression following armed robbery: patterns of appearance and impact on absenteeism and use of health care services. J Traum Stress 25: 465-468.

Belsky J, Hartman S (2014). Gene-environment interaction in evolutionary perspective: differential susceptibility to environmental influences. World Psychiatry 13: 87-89.

Belsky J, Jonassaint C, Pluess M, Stanton M, Brummett B, Williams R (2009). Vulnerability genes or plasticity genes? Mol Psychiatry 14: 746-754.

Belsky J, Pluess M (2013). Beyond risk, resilience, and dysregulation: phenotypic plasticity and human development. Dev Psychopathol 25: 1243-1261.

Bertolino E, Singh H (2002). POU/TBP cooperativity: a mechanism for enhancer action from a distance. Mol Cell 10: 397-407

Bevilacqua L, Carli V, Sarchiapone M, George DK, Goldman D, Roy A et al (2012). Interaction between FKBP5 and childhood trauma and risk of aggressive behavior. Arch Gen Psychiatry 69: 62-70.

Binder EB, Bradley RG, Liu W, Epstein MP, Deveau TC, Mercer KB et al (2008). Association of FKBP5 polymorphisms and childhood abuse with risk of posttraumatic stress disorder symptoms in adults. JAMA 299: 1291-1305.

Binder EB, Salyakina D, Lichtner P, Wochnik GM, Ising M, Putz B et al (2004). Polymorphisms in FKBP5 are associated with increased recurrence of depressive episodes and rapid response to antidepressant treatment. Nat Genet 36: 1319-1325.

Blair LJ, Nordhues BA, Hill SE, Scaglione KM, O'Leary JC 3rd, Fontaine SN et al (2013). Accelerated neurodegeneration through chaperone-mediated oligomerization of tau. J Clin Invest 123: 4158-4169.

Boscarino JA, Erlich PM, Hoffman SN, Zhang X (2012). Higher FKBP5, COMT, CHRNA5, and CRHR1 allele burdens are associated with PTSD and interact with trauma exposure: implications for neuropsychiatric research and treatment. Neuropsychiatr Dis Treat 8: 131-139.

Bouwmeester T, Bauch A, Ruffner H, Angrand PO, Bergamini G, Croughton K et al (2004). A physical and functional map of the human TNF-alpha/NF-kappa B signal transduction pathway. Nat Cell Biol 6: 97-105.

Buchmann AF, Holz N, Boecker R, Blomeyer D, Rietschel M, Witt SH et al (2014). Moderating role of FKBP5 genotype in the impact of childhood adversity on cortisol stress response during adulthood. Eur Neuropsychopharmacol 24: 837-845.

Chrousos GP, Gold PW (1992). The concepts of stress and stress system disorders. Overview of physical and behavioral homeostasis. JAMA 267: 1244-1252.

Cohen S, Janicki-Deverts D, Miller GE (2007). Psychological stress and disease. JAMA 298: 1685-1687.

Collip D, Myin-Germeys I, Wichers M, Jacobs N, Derom C, Thiery E et al (2013). FKBP5 as a possible moderator of the psychosis-inducing effects of childhood trauma. Br J Psychiatry 202: 261-268.

Dackis MN, Rogosch FA, Oshri A, Cicchetti D (2012). The role of limbic system irritability in linking history of childhood maltreatment and psychiatric outcomes in low-income, high-risk women: moderation by FK506 binding protein 5 haplotype. Dev Psychopathol 24: 1237-1252.

Davies TH, Ning YM, Sanchez ER (2002). A new first step in activation of steroid receptors: hormone-induced switching of FKBP51 and FKBP52 immunophilins. J Biol Chem 277: 4597-4600.

Denny WB, Valentine DL, Reynolds PD, Smith DF, Scammell JG (2000). Squirrel monkey immunophilin FKBP51 is a potent inhibitor of glucocorticoid receptor binding. Endocrinology 141: 4107-4113.

Dick DM, Agrawal A, Keller MC, Adkins A, Aliev F, Monroe S et al (2015). Candidate gene-environment interaction research: reflections and recommendations. Perspect Psychol Sci 10: 37-59.

Dunn EC, Solovieff N, Lowe SR, Gallagher PJ, Chaponis J, Rosand J et al (2014). Interaction between genetic variants and exposure to Hurricane Katrina on posttraumatic stress and post-traumatic growth: a prospective analysis of low income adults. J Affect Disord 152-154: 243-249.

Ellsworth KA, Eckloff BW, Li L, Moon I, Fridley BL, Jenkins GD et al (2013a). Contribution of FKBP5 genetic variation to gemcitabine treatment and survival in pancreatic adenocarcinoma. PLoS One 8: e70216.

Ellsworth KA, Moon I, Eckloff BW, Fridley BL, Jenkins GD, Batzler A et al (2013b). FKBP5 genetic variation: association with selective serotonin reuptake inhibitor treatment outcomes in major depressive disorder. Pharmacogenet Genomics 23 156-166

Ewald ER, Wand GS, Seifuddin F, Yang X, Tamashiro KL, Potash JB et al (2014). Alterations in DNA methylation of Fkbp5 as a determinant of blood-brain correlation of glucocorticoid exposure. Psychoneuroendocrinology 44: 112-122.

Fabian AK, Marz A, Neimanis S, Biondi RM, Kozany C, Hausch F (2013). InterAKTions with FKBPs-mutational and pharmacological exploration. PLoS One 8: e57508.

Fani N, Gutman D, Tone EB, Almli L, Mercer KB, Davis J et al (2013). FKBP5 and attention bias for threat: associations with hippocampal function and shape. JAMA Psychiatry 70: 392-400.

Feil R, Fraga MF (2011). Epigenetics and the environment: emerging patterns and implications. Nat Rev Genet 13: 97-109.

Franklin TB, Russig H, Weiss IC, Graff J, Linder N, Michalon A et al (2010). Epigenetic transmission of the impact of early stress across generations. Biol Psychiatry 68: 408-415.

Fries E, Hesse J, Hellhammer J, Hellhammer DH (2005). A new view on hypocortisolism. Psychoneuroendocrinology 30: 1010-1016.

Fujii T, Hori H, Ota M, Hattori K, Teraishi T, Sasayama D et al (2014a). Effect of the common functional FKBP5 variant (rs1360780) on the hypothalamic-pituitaryadrenal axis and peripheral blood gene expression. Psychoneuroendocrinology 42: 89-97.

Fujii T, Ota M, Hori H, Hattori K, Teraishi T, Matsuo J et al (2014b). The common functional FKBP5 variant rs1360780 is associated with altered cognitive function in aged individuals. Sci Rep 4: 6696.

Gaali S, Gopalakrishnan R, Wang Y, Kozany C, Hausch F (2011). The chemical biology of immunophilin ligands. Curr Med Chem 18: 5355-5379.

Gaali S, Kirschner A, Cuboni S, Hartmann J, Kozany C, Balsevich G et al (2015). Selective inhibitors of the FK506-binding protein 51 by induced fit. Nat Chem Biol 11: 33-37.

Galea S, Nandi A, Vlahov D (2005). The epidemiology of post-traumatic stress disorder after disasters. Epidemiol Rev 27: 78-91.

Gallo LI, Ghini AA, Piwien Pilipuk G, Galigniana MD (2007). Differential recruitment of tetratricorpeptide repeat domain immunophilins to the mineralocorticoid receptor influences both heat-shock protein 90-dependent retrotransport and hormonedependent transcriptional activity. Biochemistry 46: 14044-14057.

Gassen NC, Hartmann J, Zschocke J, Stepan J, Hafner K, Zellner A et al (2014). Association of FKBP51 with priming of autophagy pathways and mediation of antidepressant treatment response: evidence in cells, mice, and humans. PLoS Med 11: e1001755

Gassen NC, Hartmann J, Zannas AS, Zschocke J, Maccarrone G, Hafner K et al (2015). FKBP51 inhibits GSK3 $\beta$ and augments the effects of distinct psychotropic medications. Mol Psychiatry (in press).

Gee DG, Casey BJ (2015). The impact of developmental timing for stress and recovery. Neurobiol Stress 1: 184-194.

Gottesman II, Gould TD (2003). The endophenotype concept in psychiatry: etymology and strategic intentions. Am J Psychiatry 160: 636-645.

Hartmann J, Wagner KV, Liebl C, Scharf SH, Wang XD, Wolf M et al (2012). The involvement of FK506-binding protein 51 (FKBP5) in the behavioral and neuroendocrine effects of chronic social defeat stress. Neuropharmacology 62: 332-339.

Hernaus D, van Winkel R, Gronenschild E, Habets P, Kenis G, Marcelis M et al (2014). Brain-derived neurotrophic factor/FK506-binding protein 5 genotype by childhood trauma interactions do not impact on hippocampal volume and cognitive performance. PLoS One 9: e92722.

Hohne N, Poidinger M, Merz F, Pfister H, Bruckl T, Zimmermann P et al (2014). FKBP5 genotype-dependent DNA methylation and mRNA regulation after 
psychosocial stress in remitted depression and healthy controls. Int $J$ Neuropsychopharmacol 18: 1-9.

Holz NE, Buchmann AF, Boecker R, Blomeyer D, Baumeister S, Wolf I et al (2014). Role of FKBP5 in emotion processing: results on amygdala activity, connectivity and volume. Brain Struct Funct 220: 1355-1368.

Huang MC, Schwandt ML, Chester JA, Kirchhoff AM, Kao CF, Liang T et al (2014). FKBP5 moderates alcohol withdrawal severity: human genetic association and functional validation in knockout mice. Neuropsychopharmacology 39: 2029-2038.

Hubler TR, Denny WB, Valentine DL, Cheung-Flynn J, Smith DF, Scammell JG (2003). The FK506-binding immunophilin FKBP51 is transcriptionally regulated by progestin and attenuates progestin responsiveness. Endocrinology 144: 2380-2387.

Hubler TR, Scammell JG (2004). Intronic hormone response elements mediate regulation of FKBP5 by progestins and glucocorticoids. Cell Stress Chaperones 9: 243-252.

Ising M, Depping AM, Siebertz A, Lucae S, Unschuld PG, Kloiber S et al (2008). Polymorphisms in the FKBP5 gene region modulate recovery from psychosocial stress in healthy controls. Eur J Neurosci 28: 389-398.

Jaaskelainen T, Makkonen H, Palvimo JJ (2011). Steroid up-regulation of FKBP51 and its role in hormone signaling. Curr Opin Pharmacol 11: 326-331.

Jacobson L, Sapolsky R (1991). The role of the hippocampus in feedback regulation of the hypothalamic-pituitary-adrenocortical axis. Endocr Rev 12: 118-134.

Jensen KP, Herman Al, Morean ME, Kranzler HR, Gelernter J, Sofuoglu M (2014). FKBP5 variation is associated with the acute and chronic effects of nicotine. Pharmacogenomics J 15: 340-346.

Jin Y, Xu J, Liu H, Liu D (2014). Posttraumatic stress disorder and posttraumatic growth among adult survivors of Wenchuan earthquake after 1 year: prevalence and correlates. Arch Psychiatr Nurs 28: 67-73.

Jinwal UK, Koren J 3rd, Borysov SI, Schmid AB, Abisambra JF, Blair LJ et al (2010). The Hsp90 cochaperone, FKBP51, increases Tau stability and polymerizes microtubules. J Neurosci 30: 591-599.

Kaltsas G, Zannas AS, Chrousos GP (2012)Hypothalamic-pituitary-adrenal axis and cardiovascular diseaseln:Hjemdahl P, Rosengren A, Steptoe A(eds). Stress and Cardiovascular Disease. Springer: London, UK.

Keller MC (2014). Gene x environment interaction studies have not properly controlled for potential confounders: the problem and the (simple) solution. Biol Psychiatry 75: 18-24.

Kelly MM, King EM, Rider CF, Gwozd C, Holden NS, Eddleston J et al (2012). Corticosteroid-induced gene expression in allergen-challenged asthmatic subjects taking inhaled budesonide. Br J Pharmacol 165: 1737-1747.

Kendler KS, Karkowski LM, Prescott CA (1999). Causal relationship between stressful life events and the onset of major depression. Am J Psychiatry 156: 837-841.

Kim YS, Kim YJ, Lee JM, Kim EK, Park YJ, Choe SK et al (2012). Functional changes in myeloid-derived suppressor cells (MDSCs) during tumor growth: FKBP51 contributes to the regulation of the immunosuppressive function of MDSCs. $\mathrm{J}$ Immunol 188: 4226-4234.

Kinouchi S, Iga J, Ueno S, Yamauchi K, Numata S, Song H et al (2008). FKBP5, SERT and COMT mRNA expressions in the peripheral leukocytes during menstruation cycle in healthy reproductive females. Neurosci Lett 434: 124-128.

Klengel T, Binder EB (2013a). Allele-specific epigenetic modification: a molecular mechanism for gene-environment interactions in stress-related psychiatric disorders? Epigenomics 5: 109-112.

Klengel T, Binder EB (2015). FKBP5 allele-specific epigenetic modification in gene by environment interaction. Neuropsychopharmacology 40: 244-246.

Klengel T, Mehta D, Anacker C, Rex-Haffner M, Pruessner JC, Pariante CM et al (2013b). Allele-specific FKBP5 DNA demethylation mediates gene-childhood trauma interactions. Nat Neurosci 16: 33-41.

Koenen KC, Saxe G, Purcell S, Smoller JW, Bartholomew D, Miller A et al (2005). Polymorphisms in FKBP5 are associated with peritraumatic dissociation in medically injured children. Mol Psychiatry 10: 1058-1059.

Kohrt BA, Worthmann CM, Ressler KJ, Mercer KB, Upadhaya N, Koirala S et al (2015). Cross-cultural gene environment interactions in depression, posttraumatic stress disorder, and the cortisol awakening response: FKBP5 polymorphisms and childhood trauma in South Asia. Int Rev Psychiatry 27: 180-196.

Kraft $\mathrm{P}$, Aschard $\mathrm{H}$ (2015). Finding the missing gene-environment interactions. Eur J Epidemiol 30: 353-355

Kress C, Thomassin H, Grange T (2006). Active cytosine demethylation triggered by a nuclear receptor involves DNA strand breaks. Proc Natl Acad Sci USA 103: 11112-11117.

Lee RS, Tamashiro KL, Yang X, Purcell RH, Harvey A, Willour VL et al (2010). Chronic corticosterone exposure increases expression and decreases deoxyribonucleic acid methylation of Fkbp5 in mice. Endocrinology 151: 4332-4343.

Lee RS, Tamashiro KL, Yang X, Purcell RH, Huo Y, Rongione M et al (2011). A measure of glucocorticoid load provided by DNA methylation of Fkbp5 in mice. Psychopharmacology 218: 303-312.

Lessard J, Holman EA (2014). FKBP5 and CRHR1 polymorphisms moderate the stress-physical health association in a national sample. Health Psychol 33: 1046-1056.

Levran O, Peles E, Randesi M, Li Y, Rotrosen J, Ott J et al (2014). Stress-related genes and heroin addiction: a role for a functional FKBP5 haplotype. Psychoneuroendocrinology 45: 67-76.

Li N, Lee B, Liu RJ, Banasr M, Dwyer JM, Iwata M et al (2010). mTOR-dependent synapse formation underlies the rapid antidepressant effects of NMDA antagonists. Science 329: 959-964.

Li TK, Baksh S, Cristillo AD, Bierer BE (2002). Calcium- and FK506-independent interaction between the immunophilin FKBP51 and calcineurin. J Cell Biochem 84: $460-471$.

Lu NZ, Cidlowski JA (2005). Translational regulatory mechanisms generate $\mathrm{N}$-terminal glucocorticoid receptor isoforms with unique transcriptional target genes. Mol Cell 18: 331-342.

Luijk MP, Velders FP, Tharner A, van ljzendoorn MH, Bakermans-Kranenburg MJ, Jaddoe WW et al (2010). FKBP5 and resistant attachment predict cortisol reactivity in infants: gene-environment interaction. Psychoneuroendocrinology 35 : 1454-1461.

Lv J, Xin Y, Zhou W, Qiu Z (2013). The epigenetic switches for neural development and psychiatric disorders. J Genet Genomics 40: 339-346.

Magee JA, Chang LW, Stormo GD, Milbrandt J (2006). Direct, androgen receptormediated regulation of the FKBP5 gene via a distal enhancer element. Endocrinology 147: 590-598.

Markman B, Dienstmann R, Tabernero J (2010). Targeting the PI3K/Akt/mTOR pathway-beyond rapalogs. Oncotarget 1: 530-543.

Meaburn EL, Schalkwyk LC, Mill J (2010). Allele-specific methylation in the human genome: implications for genetic studies of complex disease. Epigenetics $\mathbf{5}$ : 578-582.

Menke A, Arloth J, Putz B, Weber P, Klengel T, Mehta D et al (2012). Dexamethasone stimulated gene expression in peripheral blood is a sensitive marker for glucocorticoid receptor resistance in depressed patients. Neuropsychopharmacology 37: 1455-1464.

Menke A, Klengel T, Rubel J, Bruckl T, Pfister H, Lucae S et al (2013). Genetic variation in FKBP5 associated with the extent of stress hormone dysregulation in major depression. Genes Brain Behav 12: 289-296.

Minelli A, Maffioletti E, Cloninger CR, Magri C, Sartori R, Bortolomasi M et al (2013). Role of allelic variants of FK506-binding protein 51 (FKBP5) gene in the development of anxiety disorders. Depress Anxiety 30: 1170-1176.

Munafo MR, Zammit S, Flint J (2014). Practitioner review: a critical perspective on gene-environment interaction models-what impact should they have on clinical perceptions and practice? J Child Psychol Psychiatry 55: 1092-1101.

Nelson ED, Kavalali ET, Monteggia LM (2008). Activity-dependent suppression of miniature neurotransmission through the regulation of DNA methylation. J Neurosci 28: 395-406.

Nicolaides NC, Charmandari E, Chrousos GP, Kino T (2014). Recent advances in the molecular mechanisms determining tissue sensitivity to glucocorticoids: novel mutations, circadian rhythm and ligand-induced repression of the human glucocorticoid receptor. BMC Endocr Disord 14: 71.

Nillni YI, Nosen E, Williams PA, Tracy M, Coffey SF, Galea S (2013). Unique and related predictors of major depressive disorder, posttraumatic stress disorder, and their comorbidity after Hurricane Katrina. J Nerv Ment Dis 201: 841-847.

O'Leary JC 3rd, Dharia S, Blair LJ, Brady S, Johnson AG, Peters M et al (2011). A new anti-depressive strategy for the elderly: ablation of FKBP5/FKBP51. PLoS One 6: e24840.

Paakinaho V, Makkonen H, Jaaskelainen T, Palvimo JJ (2010). Glucocorticoid receptor activates poised FKBP51 locus through long-distance interactions. Mol Endocrinol 24: 511-525

Pagliaccio D, Luby JL, Bogdan R, Agrawal A, Gaffrey MS, Belden AC et al (2014). Stress-system genes and life stress predict cortisol levels and amygdala and hippocampal volumes in children. Neuropsychopharmacology 39: 1245-1253.

Pagliaccio D, Luby JL, Bogdan R, Agrawal A, Gaffrey MS, Belden AC et al (2015). HPA axis genetic variation, pubertal status, and sex interact to predict amygdala and hippocampus responses to negative emotional faces in school-age children. Neuroimage 109c: 1-11.

Pei H, Li L, Fridley BL, Jenkins GD, Kalari KR, Lingle W et al (2009). FKBP51 affects cancer cell response to chemotherapy by negatively regulating Akt. Cancer Cell 16: 259-266.

Pelleymounter LL, Moon I, Johnson JA, Laederach A, Halvorsen M, Eckloff B et al (2011). A novel application of pattern recognition for accurate SNP and indel 
discovery from high-throughput data: targeted resequencing of the glucocorticoid receptor co-chaperone FKBP5 in a Caucasian population. Mol Genet Metab 104: 457-469.

Pereira MJ, Palming J, Svensson MK, Rizell M, Dalenback J, Hammar M et al (2014). FKBP5 expression in human adipose tissue increases following dexamethasone exposure and is associated with insulin resistance. Metabolism 63: 1198-1208.

Romano MF, Avellino R, Petrella A, Bisogni R, Romano S, Venuta S (2004). Rapamycin inhibits doxorubicin-induced NF-kappaB/Rel nuclear activity and enhances the apoptosis of melanoma cells. Eur J Cancer 40: 2829-2836.

Romano S, D'Angelillo A, Pacelli R, Staibano S, De Luna E, Bisogni R et al (2010). Role of FK506-binding protein 51 in the control of apoptosis of irradiated melanoma cells. Cell Death Differ 17: 145-157.

Roy A, Gorodetsky E, Yuan Q, Goldman D, Enoch MA (2010). Interaction of FKBP5, a stress-related gene, with childhood trauma increases the risk for attempting suicide. Neuropsychopharmacology 35: 1674-1683.

Roy A, Hodgkinson CA, Deluca V, Goldman D, Enoch MA (2012). Two HPA axis genes, CRHBP and FKBP5, interact with childhood trauma to increase the risk for suicidal behavior. J Psychiatr Res 46: 72-79.

Russell GM, Henley DE, Leendertz J, Douthwaite JA, Wood SA, Stevens A et al (2010). Rapid glucocorticoid receptor-mediated inhibition of hypothalamicpituitary-adrenal ultradian activity in healthy males. $J$ Neurosci 30: 6106-6115.

Russo SJ, Murrough JW, Han MH, Charney DS, Nestler EJ (2012). Neurobiology of resilience. Nat Neurosci 15: 1475-1484.

Sabbagh JJ, O'Leary JC 3rd, Blair LJ, Klengel T, Nordhues BA, Fontaine SN et al (2014). Age-associated epigenetic upregulation of the FKBP5 gene selectively impairs stress resiliency. PLoS One 9: e107241.

Sapolsky RM, Armanini MP, Packan DR, Sutton SW, Plotsky PM (1990). Glucocorticoid feedback inhibition of adrenocorticotropic hormone secretagogue release. Relationship to corticosteroid receptor occupancy in various limbic sites. Neuroendocrinology 51: 328-336.

Scammell JG, Denny WB, Valentine DL, Smith DF (2001). Overexpression of the FK506-binding immunophilin FKBP51 is the common cause of glucocorticoid resistance in three New World primates. Gen Comp Endocrinol 124: 152-165.

Scharf SH, Liebl C, Binder EB, Schmidt MV, Muller MB (2011). Expression and regulation of the Fkbp5 gene in the adult mouse brain. PLoS One 6: e16883.

Scheinman RI, Gualberto A, Jewell CM, Cidlowski JA, Baldwin AS Jr (1995). Characterization of mechanisms involved in transrepression of NF-kappa B by activated glucocorticoid receptors. Mol Cell Biol 15: 943-953.

Schiene-Fischer C, Yu C (2001). Receptor accessory folding helper enzymes: the functional role of peptidyl prolyl cis/trans isomerases. FEBS Lett 495: 1-6.

Schmidt MV, Paez-Pereda M, Holsboer F, Hausch F (2012). The prospect of FKBP51 as a drug target. ChemMedChem 7: 1351-1359.

Schmidt U, Buell DR, lonescu IA, Gassen NC, Holsboer F, Cox MB et al (2015). A role for synapsin in FKBP51 modulation of stress responsiveness: convergent evidence from animal and human studies. Psychoneuroendocrinology 52: 43-58.

Shibuya N, Suzuki A, Sadahiro R, Kamata M, Matsumoto Y, Goto K et al (2010). Association study between a functional polymorphism of FK506-binding protein 51 (FKBP5) gene and personality traits in healthy subjects. Neurosci Lett 485 194-197.

Shrestha S, Sun Y, Lufkin T, Kraus P, Or Y, Garcia YA et al (2015). Tetratricopeptide repeat domain 9A negatively regulates estrogen receptor alpha activity. Int J Biol Sci 11: 434-447.

Sinclair D, Fillman SG, Webster MJ, Weickert CS (2013). Dysregulation of glucocorticoid receptor co-factors FKBP5, BAG1 and PTGES3 in prefrontal cortex in psychotic illness. Sci Rep 3: 3539.

Sinha R (2007). The role of stress in addiction relapse. Curr Psychiatry Rep 9: 388-395.

Sriram K, Rodriguez-Fernandez M, Doyle FJ 3rd (2012). Modeling cortisol dynamics in the neuro-endocrine axis distinguishes normal, depression, and post-traumatic stress disorder (PTSD) in humans. PLoS Comput Biol 8: e1002379.

Stechschulte LA, Sanchez ER (2011). FKBP51-a selective modulator of glucocorticoid and androgen sensitivity. Curr Opin Pharmacol 11: 332-337.

Suzuki A, Matsumoto Y, Sadahiro R, Enokido M, Goto K, Otani K (2014). Relationship of the FKBP5 $\mathrm{C} / \mathrm{T}$ polymorphism with dysfunctional attitudes predisposing to depression. Compr Psychiatry 55: 1422-1425.

Telese F, Gamliel A, Skowronska-Krawczyk D, Garcia-Bassets I, Rosenfeld MG (2013). 'Seq-ing' insights into the epigenetics of neuronal gene regulation. Neuron 77: $606-623$

Thomassin H, Flavin M, Espinas ML, Grange T (2001). Glucocorticoid-induced DNA demethylation and gene memory during development. EMBO J 20: 1974-1983.

Touma C, Gassen NC, Herrmann L, Cheung-Flynn J, Bull DR, lonescu IA et al (2011). FK506 binding protein 5 shapes stress responsiveness: modulation of neuroendocrine reactivity and coping behavior. Biol Psychiatry 70: 928-936.
Tsolaki M, Kounti F, Karamavrou S (2009). Severe psychological stress in elderly individuals: a proposed model of neurodegeneration and its implications. Am J Alzheimers Dis Other Demen 24: 85-94.

U M, Shen L, Oshida T, Miyauchi J, Yamada M, Miyashita T (2004). Identification of novel direct transcriptional targets of glucocorticoid receptor. Leukemia 18 1850-1856.

Uchida S, Hara K, Kobayashi A, Otsuki K, Yamagata H, Hobara T et al (2011). Epigenetic status of Gdnf in the ventral striatum determines susceptibility and adaptation to daily stressful events. Neuron 69: 359-372.

van Winkel R, Stefanis NC, Myin-Germeys I (2008). Psychosocial stress and psychosis. A review of the neurobiological mechanisms and the evidence for gene-stress interaction. Schizophr Bull 34: 1095-1105.

VanZomeren-Dohm AA, Pitula CE, Koss KJ, Thomas K, Gunnar MR (2015). FKBP5 moderation of depressive symptoms in peer victimized, post-institutionalized children. Psychoneuroendocrinology 51: 426-430.

Vermeer $\mathrm{H}$, Hendriks-Stegeman BI, van der Burg B, van Buul-Offers SC, Jansen M (2003). Glucocorticoid-induced increase in lymphocytic FKBP51 messenger ribonucleic acid expression: a potential marker for glucocorticoid sensitivity, potency, and bioavailability. J Clin Endocrinol Metab 88: 277-284.

Watts AG (2005). Glucocorticoid regulation of peptide genes in neuroendocrine $\mathrm{CRH}$ neurons: a complexity beyond negative feedback. Front Neuroendocrinol 26 109-130.

Weaver IC, Cervoni N, Champagne FA, D'Alessio AC, Sharma S, Seckl JR et al (2004). Epigenetic programming by maternal behavior. Nat Neurosci 7: 847-854.

Wei XE, Zhang FY, Wang K, Zhang QX, Rong LQ (2014). Assembly of the FKBP51PHLPP2-AKT signaling complex in cerebral ischemia/reperfusion injury in rats. Brain Res 1566: 60-68.

Weiwad M, Edlich F, Kilka S, Erdmann F, Jarczowski F, Dorn M et al (2006). Comparative analysis of calcineurin inhibition by complexes of immunosuppressive drugs with human FK506 binding proteins. Biochemistry 45: 15776-15784.

White MG, Bogdan R, Fisher PM, Munoz KE, Williamson DE, Hariri AR (2012). FKBP5 and emotional neglect interact to predict individual differences in amygdala reactivity. Genes Brain Behav 11: 869-878.

Wiederrecht G, Hung S, Chan HK, Marcy A, Martin M, Calaycay J et al (1992). Characterization of high molecular weight FK-506 binding activities reveals a novel FK-506-binding protein as well as a protein complex. J Biol Chem 267: 21753-21760.

Wilker S, Pfeiffer A, Kolassa S, Elbert T, Lingenfelder B, Ovuga E et al (2014). The role of FKBP5 genotype in moderating long-term effectiveness of exposure-based psychotherapy for posttraumatic stress disorder. Trans/ Psychiatry 4: e403.

Willour VL, Chen H, Toolan J, Belmonte P, Cutler DJ, Goes FS et al (2009). Familybased association of FKBP5 in bipolar disorder. Mol Psychiatry 14: 261-268.

Wochnik GM, Ruegg J, Abel GA, Schmidt U, Holsboer F, Rein T (2005). FK506binding proteins 51 and 52 differentially regulate dynein interaction and nuclear translocation of the glucocorticoid receptor in mammalian cells. J Biol Chem 280: 4609-4616.

Woodruff PG, Boushey HA, Dolganov GM, Barker CS, Yang YH, Donnelly S et al (2007). Genome-wide profiling identifies epithelial cell genes associated with asthma and with treatment response to corticosteroids. Proc Natl Acad Sci USA 104: 15858-15863.

Xie P, Kranzler HR, Poling J, Stein MB, Anton RF, Farrer LA et al (2010). Interaction of FKBP5 with childhood adversity on risk for post-traumatic stress disorder. Neuropsychopharmacology 35: 1684-1692.

Yang X, Ewald ER, Huo Y, Tamashiro KL, Salvatori R, Sawa A et al (2012). Glucocorticoid-induced loss of DNA methylation in non-neuronal cells and potential involvement of DNMT1 in epigenetic regulation of Fkbp5. Biochem Biophys Res Commun 420: 570-575.

Yehuda R, Daskalakis NP, Desarnaud F, Makotkine I, Lehrner AL, Koch E et al (2013). Epigenetic biomarkers as predictors and correlates of symptom improvement following psychotherapy in combat veterans with PTSD. Front Psychiatry 4: 118

Yehuda R, Southwick SM, Nussbaum G, Wahby V, Giller EL Jr, Mason JW (1990). Low urinary cortisol excretion in patients with posttraumatic stress disorder. J Nerv Ment Dis 178: 366-369.

Zannas AS, Binder EB (2014a). Gene-environment interactions at the FKBP5 locus: sensitive periods, mechanisms and pleiotropism. Genes Brain Behav 13: 25-37.

Zannas AS, West AE (2014b). Epigenetics and the regulation of stress vulnerability and resilience. Neuroscience 264: 157-170.

Zimmermann P, Bruckl T, Nocon A, Pfister H, Binder EB, Uhr $\mathrm{M}$ et al (2011). Interaction of FKBP5 gene variants and adverse life events in predicting depression onset: results from a 10-year prospective community study. Am J Psychiatry 168: 1107-1116.

Zou YF, Wang F, Feng XL, Li WF, Tao JH, Pan FM et al (2010). Meta-analysis of FKBP5 gene polymorphisms association with treatment response in patients with mood disorders. Neurosci Lett 484: 56-61. 